\title{
O (TRANS)CONSTITUCIONALISMO, O DIREITO INTERNACIONAL E O DIREITO DO TRABALHO: UM COMPLEXO NORMATIVO EM BUSCA DA PROTEÇÃO AO TRABALHADOR BRASILEIRO
}

\author{
THE (TRANS)CONSTITUCIONALISMO, INTERNATIONAL LAW AND LABOR \\ LAW: A NORMATIVE COMPLEX IN PURSUIT OF PROTECTING BRAZILIAN \\ WORKER
}

Eu vejo a vida melhor no futuro. Eu vejo isso por cima de um muro. De hipocrisia que insiste em nos rodear. Eu vejo a vida mais clara e farta. Repleta de toda satisfação. Que se tem direito do firmamento ao chão.

Lulu Santos

\begin{abstract}
Resumo
Considerando que a globalização, a terceira revolução industrial e a internacionalização da produção ocasionaram efetivas mudanças no mundo contemporâneo, a ciência do Direito diretamente foi provocada para que pudesse ofertar as respectivas respostas aos seus jurisdicionados. E daí surge no direito constitucional o fenômeno do transconstitucionalismo, servindo de base para um novo formato de Constituição, através de inclusão e recepção dos tratados e convenções internacionais no âmbito nacional, que podem servir para aumentar os direitos trabalhistas existentes no ordenamento jurídico brasileiro, sempre efetivando o princípio da proteção, ponto norteador do Direito do Trabalho.
\end{abstract}

Palavra-Chave: Globalização. Direito Constitucional. Direito Internacional. Direito do Trabalho. Proteção ao trabalhador.

\begin{abstract}
Whereas globalization, the third industrial revolution and the internationalization of production brought about effective changes in the contemporary world, the science of law was directly triggered so that it could offer the answers to their jurisdictional. And then come the constitutional right of the phenomenon transconstitucionalismo, providing the basis for a new format of the Constitution through inclusion, reception of international treaties and conventions at the national, which may serve to increase existing labor rights in the Brazilian legal system, always making the principle of protection, guiding point of the Labour Law.
\end{abstract}

Keywords: Globalization. Constitutional Law. International Law. Labor Law. Worker protection. 


\section{INTRODUÇÃO}

O tempo é um grande companheiro do homem, sendo capaz de ofertar transformações que o ser humano nunca imaginou e até mesmo descobrir, inventar produtos e novas formas de trabalho até então jamais pensadas.

As alterações sofridas pela sociedade contemporânea, dar-se-á por um complexo de fatores, como: a globalização, terceira revolução industrial (robótica, cibernética), formação de blocos econômicos e internacionalização do comércio e do trabalho.

Antigamente a distância física era capaz de afastar as pessoas, diante da falta de mecanismos de comunicação e pela dificuldade de locomoção. Atualmente tais fatos já não são problemas, afinal foram criadas inúmeras formas de diálogos entre pessoas que fisicamente encontram-se afastadas (até mesmo em continentes distintos), através de computadores ou telefones (que fazem de tudo, ofertando um número plástico de aplicativos e redes socais) e os meios de locomoção foram aprimorados.

A globalização trouxe diversos efeitos ao mundo contemporâneo, sendo que um deles é a relativização da soberania dos Estados, ensejando a criação dos blocos econômicos e sociais ${ }^{1}$. As nações encontram-se cada vez mais interligadas, interconectadas e interdependentes.

Um novo mundo vem sendo formado através das novas perspectivas, sendo que o "Estado contemporâneo tem o seu perfil redefinido pela formação de blocos econômicos, pela perda da densidade do conceito de soberania, pelo aparente esvaziamento do seu poder diante de globalização". ${ }^{2}$

E, como cabe ao Direito acompanhar as mudanças ocorridas no mundo para assim ofertar a devida segurança jurídica aos jurisdicionados, também ficou alterado sofrendo substanciais reformas.

Muito embora o mundo contemporâneo esteja sofrendo algumas transformações, através dos zonas econômicas e sociais, o Estado continua sendo o

\footnotetext{
${ }^{1}$ Veja-se a União Europeia que abrange atualmente 28 países europeus; o Mercosul que englobou inicia lmente o Brasil, Argentina, Paraguai e Uruguai e o Nafta composto pelos Estados Unidos, Canadá e M éxico.

${ }^{2}$ BARROSO. Luís Roberto. Curso de direito constitucional Contemporâneo: os conceitos fundamentais e a construção do novo modelo. $4^{\mathrm{a}}$ ed. São Paulo: Saraiva, 2013, p. 91.
} 
"protagonista na história da humanidade, seja no plano internacional, seja no plano doméstico". ${ }^{3}$

Sendo assim, o presente artigo tem como objetivo demonstrar que a partir da mudança da sociedade, o constitucionalismo também foi alterado, atingindo diretamente o Direito do Trabalho, tornando-o internacionalizado e globalizado, fazendo com que tratados e convenções internacionais ganhassem importância no ordenamento jurídico.

\section{UMA PEQUENA ANÁllSE DA RELAÇÃO ENTRE O HOMEM E O TRABALHO}

O trabalho é uma das práticas mais antigas do homem, acompanhando-o desde os primórdios, no dito comunismo primitivo, passando pelo escravismo, feudalismo, permanecendo até a presente data no vigente sistema capitalista de produção.

Luiz Otávio Linhares Renault demonstra essa relação:

Desde os primórdios da humanidade até a época atual, o trabalho tem sido condição sine qua non para a sobrevivência a para o crescimento moral, espiritual, religioso, intelectual, cultural, científico e material do homem. ${ }^{4}$

Por trabalho pode-se entender como a transformação da natureza de forma voluntária e consciente ou então como "toda energia humana física ou intelectual, empregada com um fim produtivo."

Para Karl Marx e Friedrich Engels, a relação entre homem e trabalho, representa "a história de todas as sociedades" 6

Daí, pode-se dizer que o homem e o trabalho são faces da mesma moeda, um dependendo do outro para sua plena realização e inclusive que o trabalho é a premissa

\footnotetext{
${ }^{3}$ Idem, p. 92.

${ }^{4}$ RENAULT, Luiz Otávio Linhares. Que é isto - o direto do trabalho. In: PIMENTA, José Roberto Fre ire et al. (Coords.). Direito do trabalho: evolução, crise, perspectiva. São Paulo: LTr, 2004, p. 46.

${ }^{5}$ SÜSSEKIND, Arnaldo. Curso de direito do trabalho. $3^{\text {a }}$ ed. rev. e atual. Rio de Janeiro: Renovar, 201 0, p. 03.

${ }^{6}$ MARX, Karl Heinrich; ENGELS, Friedrich. Manifesto do partido comunista 1848. Tradução Osvaldo Coggiola. 5a reimpressão. São Paulo: Editora Boitempo, 2007, p. 40.
} 
do sistema socioeconômico de um determinando momento histórico, capaz de ensejar a conhecida "luta de classes". 7

\subsection{DO COMUNISMO PRIMITIVO}

Durante a pré-história (quando ainda não existia a figura do Estado), no dito comunismo primitivo, período que os homens eram nômades e andavam a procura de alimentos. Descobriram e passaram a dominar o fogo. Possuíam uma linguagem rudimentar e desenvolveram as primeiras práticas de magia (devido à descoberta do fogo), bem como a escrita e a fala.

Uma das principais características desta época é a ausência da propriedade privada, quando tudo era de todos e o trabalho era feito de forma coletiva, bem como a repartição dos resultados. Conforme ilustra Lorena Vasconcelos Porto: "a propriedade de tais meios (terras, utensílios, ferramentas) pertencia a toda a sociedade, todos os seus membros trabalhavam e tinham acesso aos frutos produzidos ${ }^{8}$.

Quanto ao comunismo primitivo, lecionam Karl Marx e Friedrich Engels:

A pré-História, a organização social anterior à história escrita era desconhecida em 1847. Mais tarde, Haxthausen (August von, 17921866) descobriu a propriedade comum da terra na Rússia, Maurer (Georg Ludwig von) mostrou ter sido essa a base social da qual as tribos teutônias derivaram historicamente e, pouco a pouco, verificou-se que a comunidade rural era a forma primitiva da sociedade, desvendada, em sua forma típica, pela descoberta e Morgan (Lewis Henry, 1818-81) da verdadeira natureza de gens e de sua relação com a tribo. Após a dissolução dessas comunidades primitivas, a sociedade passou a dividir-se em classes distintas. ${ }^{9}$

Neste modelo de produção as classes inexistia a ideia de classes sociais neste momento histórico.

\footnotetext{
${ }^{7}$ Idem, p. 40.

${ }^{8}$ PORTO, Lorena Vasconcelos. A subordinação no contrato de emprego: desconstrução, reconstrução e universalização do conceito jurídico. 2009. Dissertação (Mestrado) - Faculdade Mineira de Direito da Pontifícia Universidade Católica de Minas Gerais, Belo Horizonte, 2009, p. 22.

${ }^{9}$ MARX, Karl Heinrich; ENGELS, Friedrich. Manifesto do partido comunista 1848. Tradução Osvaldo Coggiola. 5a reimpressão. São Paulo: Editora Boitempo, 2007, p. 40.
} 


\subsection{DA ESCRAVIDÃO}

Posteriormente, surge a figura do Estado, e com isso, se inicia o sistema da escravidão (Antiguidade - 4000 a.C a 476 d.C), é pautado pela relação entre os escravos e o os senhores. Conforme leciona Paulo Bonavides: "O Estado como ordem política da Sociedade é conhecido desde a Antiguidade aos nossos dias." ${ }^{10}$ Os escravos eram despossuídos de qualquer tratamento jurídico, ou seja, não tinham qualquer direito, tendo em vista que eram considerados coisas, pertencentes ao seu senhor. Aparece então o domínio de uma classe (detentores dos meios de produção) sobre a outra (trabalhadora), sujeição.

Com o passar do tempo, os senhores que passaram a acumular um grande número de escravos, passaram a vendê-los, trocá-los ou alugá-los à sua revelia. Ou seja, os escravos viraram moedas.

A relação senhor e escravo foi muito bem demonstrada por Hegel, ilustrando “que o escravo reconhecia o Senhor como sujeito, mas o Senhor não reconhecia o escravo como sujeito, portanto, o escravo não tinha consciência de si, assumindo uma posição de objeto (coisa)."11

Ao contrário do comunismo primitivo, os frutos advindos do trabalho pertenciam tão somente a um determinada classe: os senhores.

O Estado sendo uma figura institucional, imposta e não natural, antigamente representava os interesses da classe detentora do poderio econômico, permitindo o abuso sofrido pela classe trabalhadora.

\subsection{DO FEUDALISMO}

Durante o Império Romano, o Estado foi denominado como Imperium e Regnum (fazendo e traduzindo ideia de força), e foi o último grande império ocidental caracterizado pelo regime escravocrata e teve sua derrocada no século $\mathrm{V}$ d. C, surgindo a Idade Média (476 a 1453 d.C), quando o era chamado de Laender (países), quando o sistema preponderante foi o feudalismo, pautado pela existência de uma nova classe trabalhadora: os servos.

\footnotetext{
${ }^{10}$ BONAVIDES, Paulo. Ciência política. $20^{\mathrm{a}}$ impressão. São Paulo: Malheiros Editores, 2013, p. 64.

${ }^{11}$ HEGEL, Georg Wilhelm Friedrich. A razão na história. São Paulo: Editora Centauro, p. 120.
} 
Os servos substituíram os antigos escravos, e assim como eles de fato, não eram livres, vez que estavam ligados a terra em que se encontravam e seguiam a sorte desta. O servo não dispunha de sua liberdade, estando sujeito a severas restrições, inclusive de deslocamento.

Na Idade Média surge todo o arcabouço da organização industrial, que iniciouse com o sistema familiar, quando membros da uma família produziam artigos para consumo próprio, subsistência e não para a venda, comércio. Após veio o sistema das corporações, com a criação das Corporações de Artes e Ofício, verdadeiros núcleos de produção ${ }^{12}$, liderados pelos artesões e artífices do escravismo. Essas corporações eram formadas pelos mestres, os companheiros (trabalhadores) e aprendizes. Diante da inexistência das máquinas, a palavra que imperava era: habilidade, capacidade de produzir com as próprias mãos. Os mestres possuíam contato direto com os consumidores, conseguiam entender seus anseios e suas vontades, negociavam diretamente os seus produtos com as pessoas.

Quanto a figura dos mestres, demonstra o historiador Leo Hubeman:

O mestre artesão fora mais do que um simples fabricante de produtos. Tinha também quatro outras funções. Era cinco pessoas numa só. Quando procurava a matéria-prima que utilizava, era negociante ou mercador; tendo jornaleiros e aprendizes sob seu mando, era empregador; ao supervisionar o trabalho deles, era capataz; e como vendia ao consumidor, no balcão, o produto acabado, era também um comerciante lojista. ${ }^{13}$

No início, os aprendizes podiam se tornar mestres, desde que executassem um trabalho perfeito, uma obra-prima. Mais tarde, só os filhos de mestres ou os companheiros que pagassem altas taxas conseguiam alcançar a maestria. Neste momento histórico, surge uma nova classe emergencial: a burguesia, que comercializava os produtos fabricados nas Corporações. A burguesia apareceu realizando o papel de intermediador, locando-se entre o mestre e o consumidor:

Entra em cena o intermediário, e as cinco funções do mestre artesão se reduziram a três - trabalhador, empregador, capataz. Os ofícios de mercador e comerciante deixaram de ser atribuição sua. O intermediário lhe entrega a matéria-prima e recebe o produto

\footnotetext{
${ }^{12}$ As Corporações de Artes e Ofício eram também conhecidas como Associações de Artes e Misteres e se desenvolveram com maior destaque na França, Espanha, Alemanha e Inglaterra.

${ }^{13}$ HUBERMAN, Leo. História de riqueza do homem. Tradução de Waltensir Dutra: atualização e revisão técnica Marcia Guerra. 22 $2^{\mathrm{a}}$ rev e ampl. Rio de Janeiro: LTR, 2011, p. 89.
} 
acabado. O intermediário coloca-se entre ele e o comprador. A tarefa do mestre artesão passou a ser simplesmente produzir mercadorias acabadas tão logo recebe a matéria-prima. ${ }^{14}$

Com o surgimento desta nova classe, denominada intermediário ou burguesia, o sistema de corporações é substituído no Século XVI, pelo sistema doméstico, o qual o mestre muito embora fosse o detentor dos meios de produção, recebia a matéria prima do intermediário/burguês. A partir de então, quem passou a negociar a mercadoria pronta foi a burguesia, o intermediador, perdurando esta situação até o Século XVIII.

\subsection{DO CAPITALISMO}

Com o fim do feudalismo, encerra-se a Idade Média e surge a Idade Moderna (1453 a 1789 d. C), “o Estado moderno surge no início do século XVI, ao final da Idade Média, sobre as ruínas do feudalismo. Nasce absolutista, por circunstância e necessidade, com seus monarcas ungidos por direito divino, permanecendo pautado pelo sistema da servidão". ${ }^{15}$

A Idade Moderna foi pautada pelo Estado Absolutista, quando os poderes políticos e econômicos se concentravam na realeza, situação ilustrada por Luís XIV: “L'État c'est moi”. No século XVIII, o absolutismo é derrocado através das revoluções burguesas: inglesa (1688), americana (1776), francesa (1789), que dá ensejo ao Estado de Direito, a partir do constitucionalismo, ocasião em que o sistema socioeconômico passou a ser o capitalismo (teoria da acumulação) e não mais a servidão.

Quanto as revoluções burguesas, comenta Ingo Wolfgang Sarlet:

Com o incremento do capitalismo como modo de produção, primeiramente com o incremento e expansão das revoluções comerciais a partir do final da Idade Média, e depois por via de seu modelo industrial oriundo da revolução econômica na Inglaterra, a burguesia revela-se como o setor mais avançado e dinâmico da sociedade, avultando cada vez mais, o contraste entre sua posição econômica e ausência de sua participação no poder político. Assim,

\footnotetext{
${ }^{14}$ Idem, p. 89.

15 BARROSO. Luís Roberto. Curso de direito constitucional Contemporâneo: os conceitos fundamentais e a construção do novo modelo. $4^{a}$ ed. São Paulo: Saraiva, 2013, p. 31.
} 
inevitável o choque de interesses, findando na eclosão de movimentos revolucionários que iriam contestar os privilégios da monarquia do antigo regime, inclusive em termo de secessão por parte das colônias, não apenas nos Estados Unidos (1776-1783) e na França (1789-1799) - seguramente as duas mais importantes para o constitucionalismo -, mas também na Irlanda (1783-1784), na Bélgica (1787-1790), na Holanda (1783-1787) e, inclusive, na Inglaterra (1779), que havia passado por um período de intensa agitação político-institucional, inclusive por uma guerra civil, ao longo do século XVI. ${ }^{16}$

José Adércio Leite Sampaio demostrando a conexão entre as revoluções burguesas e o constitucionalismo:

O turbilhão de mudanças que ocorreram na Europa desde 1100 e, especialmente, do curso dos séculos XVI e XVIII não encontrou espaço suficiente para tornar-se realidade sem um ato material e simbólico de mudança. Embora tenha dominado na Inglaterra (com o pensamento Whig) e depois na França (com o termidorianismo) um processo mais evolutivo que explosivo de transformações, para alguns, mais conservador também, os dois principais Estados europeus viveram momentos de intensa mobilização e violência. Esse ambiente de consciências convulsionadas foi, de certa maneira, exportado para o Novo Mundo, com especial ênfase para os Estados Unidos, associando-se ali ao movimento de independência. ${ }^{17}$

\section{DO CONSTITUCIONALISMO}

Durante o sistema capitalista de produção, o processo do constitucionalismo moderno, intitulado como "constitucionalismo moderno e contemporâneo""18 iniciouse no Século XVIII, a partir das revoluções burguesas, especificamente a inglesa (1688), norte-americana (1776) e francesa (1789), que inquestionavelmente refletiram no mundo ocidental quase que por completo no caminho do Estado de Direito liberal.

Por constitucionalismo pode-se entender como uma doutrina de limitação; separação dos Poderes; supremacia da lei e a garantia dos direitos.

\footnotetext{
${ }^{16}$ SARLET, Ingo Wolfgang; MARINONI, Luiz Guilherme; MITIDIERO. Curso de direito constitucional. $2^{\mathrm{a}}$ ed. São Paulo: Editora Revista dos Tribunais, 2013, p. 40.

${ }^{17}$ SAMPAIO, José Adércio Leite. Teoria da constituição e dos direitos fundamentais. Belo Horizonte: Del Rey, 2013, p. 14.

18 BARROSO. Luís Roberto. Curso de direito constitucional contemporâneo: os conceitos fundamentais e a construção do novo modelo. $4^{\text {a }}$ ed. São Paulo: Saraiva, 2013, p. 32.
} 
José Joaquim Gomes Canotilho entente que, ”é a teoria (ideologia) que ergue o princípio do governo limitado indispensável à garantia dos direitos em dimensão estruturante da organização político-social de uma comunidade."19

No que diz respeito a inglesa, caracterizada pela afirmação do sistema parlamentar e a implementação de uma monarquia constitucional, leciona Gabriela Neves Delgado:

A Revolução Inglesa que marcou início da era das revoluções burguesas teve forte efeito multiplicador, divulgando para além das fronteiras da Grã-Bretanha os preceitos liberais que passaram a predominar no século XVIII. ${ }^{20}$

Muito embora o fenômeno do constitucionalismo moderno tenha surgido na Inglaterra de forma não escrita, serviu da paradigma para outros, tendo em vista a previsão da limitação do poder estatal; do processo legislativo formal; das garantias civis e um parlamentarismo de cunho de representação popular.

Já quanto aos Estados Unidos, sua Constituição de 1787, marcou a emancipação das colônias, tendo sido a primeira formalizada (escrita) na História, contendo somente 7 artigos, instituindo o presidencialismo, o federalismo e o republicanismo; o governo constitucional e legal; um executivo unipessoal, tanto no plano estadual, como federal; a separação dos poderes e trouxe expressamente os direitos fundamentais da primeira dimensão.

Quanto à Constituição norte-americana, leciona Ingo Wolfgang Sarlet:

Na América do Norte, mediante a Declaração da Independência das antigas treze colônias inglesas e a posterior fundação do Estado Federal, com a promulgação da Constituição de 1787, a formação do constitucionalismo moderno adquiriu paradigmáticas. Uma das peculiaridades que marca o estágio inicial da evolução constitucional norte-americana reside na circunstância de que a criação da Constituição (a primeira constituição escrita no sentido moderno do termo) coincidiu com a própria formação do país como nação independente. O constitucionalismo republicano dos Estados Unidos fundou um novo sistema político, apto a garantir a independência das trezes antigas colônias inglesas, estabelecendo regras gerais de atuação política e consagrando direitos naturais de pessoa humana, especialmente com ênfase na eliminação dos

\footnotetext{
${ }^{19}$ CANOTILHO, José Joaquim Gomes. Direito constitucional e teoria da constituição. $7^{\mathrm{a}}$ ed, $13^{\mathrm{a}}$ reimpressão. Coimbra: Edições Almedina, 1941, p. 51.

${ }^{20}$ DELGADO, Gabriela Neves. Direito fundamental ao trabalho digno. São Paulo: LTr, 2006, p. 54.
} 
entraves às atividades econômicas, que caracterizavam a época de tutela colônia britânica. ${ }^{21}$

Em breves linhas, pode-se dize que o ponto crucial e marcante do constitucionalismo norte-americano foi a separação das colônias inglesas na América, a elaboração de uma carta constitucional escrita, que deveria servir de parâmetro para todo o ordenamento jurídico e que instituiria uma ordem política, através da soberania popular. Foi a primeira constituição formal a instituir um República Federativa, ainda efetivou as ideias de Montesquieu (separação dos poderes) e de John Locke e consagrou o governos das leis (supremacia das leis).

O constitucionalismo francês ocorreu após a inglesa e o norte-americano, e trouxe consigo caraterísticas marcantes, através da tríade: liberdade, igualdade e fraternidade, e principalmente a ideia de um novo regime político e social e da soberania popular. A transformação política e social foi um fato significativo acarretado pela revolução francesa.

Em 1791 foi promulgada a primeira constituição francesa, lecionando Ingo Wolfgang Sarlet:

Registre-se que umas das peculiaridades do desenvolvimento constitucional francês, especialmente quando confrontado com o norte americano, reside nas características do Poder Constituinte. Contrariamente do que sucedeu nos Estados Unidos, a Assembleia Nacional Constituinte na França significava uma ruptura com o passado, no sentido não apenas da fundação de um Estado, mas de uma nova ordem social, afetando profundamente até o âmbito mais elementar da sociedade. Nesse sentido, a declaração dos direitos fundamentais não objetivava apenas a limitação do poder do Estado, mas também, e sobretudo, a extinção do direito feudal e dos privilégios da aristocracia. ${ }^{22}$

O constitucionalismo francês, que sofreu grande influência da Declaração dos Direitos do Homem e do Cidadão, de 1789, ficou marcado pela transformação da ordem política e social, através da elaboração de uma constituição formal, universalista, racionalista e que previa a soberania popular, tornando-se inquestionavelmente o paradigma do Estado de Direito, de cunho liberal.

\footnotetext{
${ }^{21}$ SARLET, Ingo Wolfgang; MARINONI, Luiz Guilherme; MITIDIERO. Curso de direito constitucional. $2^{\mathrm{a}}$ ed. São Paulo: Editora Revista dos Tribunais, 2013, p. 272.

${ }^{22}$ Idem, p. 272.
} 


\subsection{Do constitucionalismo liberal}

Dentre os diversos fatores que ensejaram as revoluções burguesas, destaca-se a insatisfação desta nova classe social com a intervenção da monarquia nos comércios que realizavam dos produtos fabricados nas Corporações de Artes e Ofícios.

Através do constitucionalismo moderno, no Século XVIII, surge o Estado de Direito, de cunho liberal. Este modelo, deve ser observado através da perspectiva da limitação estatal, que fornece duas angulações: (1) o Estado passava a ficar submetido às leis, sendo que seu poder seria fracionado e não mais concentrado em uma única pessoa - como antes no absolutismo; (2) o liberalismo, tanto no campo político, como no econômico.

Neste contexto histórico são criados os direitos fundamentais da primeira dimensão: a liberdade e a igualdade.

A liberdade, deve ser analisada tanto na perspectiva econômica, como na política.

Quanto a primeira, é que conforme anteriormente já analisado, um dos anseios da burguesia era o livre comércio, negociar livremente as mercadorias. Era necessário ter a máquina estatal ao seu lado (e não em sentido contrário com a ingerência, taxação ou cobrança de impostos), para assim fomentar a economia e circulação dos bens (e assim acumular riqueza, alcançando o lucro, a tônica do capitalismo).

Conforme leciona José Joaquim Gomes Canotilho:

A economia capitalista necessita da segurança jurídica e a segurança jurídica não estava garantida no Estado Absoluto, dadas as frequentes intervenções do príncipe na esfera jurídico-patrimonial dos súbditos e o direito discricionário do mesmo príncipe quanto à alteração e revogação das leis. Ora, toda a construção constitucional liberal tem em vista a certeza do direito. O laço que liga ou vincula às leis gerais as funções estaduais protege o sistema da liberdade codificada do direito privado burguês e a economia do mercado. ${ }^{23}$

No que diz respeito a liberdade política determinava que os cidadãos a partir de então eram livres para conduzir suas próprias vidas, sendo vedada a ingerência estatal na esfera individual do cidadão.

\footnotetext{
${ }^{23}$ CANOTILHO, José Joaquim Gomes. Direito constitucional e teoria da constituição. $7^{\mathrm{a}}$ ed, $13^{\mathrm{a}}$ reimpressão. Coimbra: Edições Almedina, 1941, p. 109.
} 
Esta liberdade acabou servindo de premissa para a dominação de uma classe (burguesia) social perante outra (trabalhadores, abrangendo mulheres e menores), tendo em vista que como eram livres para dispor da sua própria vida, bem como, eram despossuídos de condições mínimas básicas, vendiam sua liberdade para ter do que sobreviver.

E justamente essa liberdade que permitirá o ser humano dispor da sua mão de obra que seria utilizada no século XIX, na Primeira Revolução Industrial, com o surgimento da máquina a vapor, o sistema doméstico deixa de ser o paradigma, dando lugar ao modelo fabril, situação ilustrada pelo historiador australiano Geoffrey Blainey:

O vapor, como força motriz, foi usado pela primeira vez com eficácia nas minas da Inglaterra. Em 1689, Thomas Savery aplicou o vapor produzido pelo carvão para fazer funcionar as bombas de uma mina da região da Cornualha. Onze anos depois, um ferreiro de Devon, Thomas Newcomen, construiu uma máquina capaz de realizar o trabalho de um exército de homens ou cavalos. Mas foi o escocês James Watt que acrescentou melhorias fundamentais à máquina a vapor. Seu maravilhoso invento de 1769 , o condensador, conseguia produzir cerca de três vezes a quantidade de vapor ou energia gerada por uma tonelada de carvão. Praticamente todos os grandes passos na evolução da máquina a vapor foram dados pelos engenhosos britânicos ao tentarem resolver os problemas práticos que surgiam no dia a dia do trabalho no setor industrial, então em desenvolvimento. ${ }^{24}$

No sistema fabril, os mestres não possuíam mais os meios de produção (como antes no sistema doméstico). Ou seja, tanto a matéria prima como os utensílios pertenciam unicamente a burguesia/intermediador. Com isso os mestres tornaram-se companheiros (trabalhadores). Com surgimento da máquina e tão logo com contato do homem com ela, a palavra a habilidade do trabalho deixou de ser importante, dando lugar ao comprometimento, disciplina às ordens recebidas. $\mathrm{O}$ trabalhador tinha que ser parecido até mesmo com as maquinas. Pensar não era necessário, e sim produzir o maior número possível de produtos, com o mínimo de custo, para assim aumentar o lucro do empregador.

Quanto a mudança das Corporações da Artes e Ofícios para as Industrias, ensina Leo Huberman:

\footnotetext{
${ }^{24}$ BLAINEY, Geoffrey. Uma breve história do mundo. São Paulo: Editora Fundamento Educacional, 2010, p. 254.
} 
Produzir mercadorias para um mercado pequeno e estável, onde o produtor fabrica o artigo para o freguês que vem ao seu local de trabalho e lhe faz uma encomenda, é uma coisa. Mas produzir para um mercado que ultrapassou os limites de uma cidade, adquirindo um alcance nacional ou mais, é outra coisa inteiramente diferente. A estrutura das corporações destinava-se ao mercado local: quando este se tornou nacional e internacional, a corporação deixou de ter utilidade. Os artesãos locais podiam entender e realizar o comércio de uma cidade, mas o comércio mundial era coisa totalmente diversa. A ampliação do mercado criou o intermediário, que chamou a si a tarefa de fazer com que as mercadorias produzidas pelos trabalhadores chegassem ao consumidor, que podia estar a milhares de distância. ${ }^{25}$

Posteriormente, ocorreu a Segunda Revolução Industrial, caracterizada pela descoberta de energia elétrica, sendo instalados novos modos de produção, baseados em Frederick Taylor e Henry Ford. Tanto no modelo produtivo taylorista, como no fordista, cabia ao trabalhador exercer seu labor de forma quase mecânica. No segundo modelo de produção, os empregados poderiam ser considerados até mesmo segmentos das máquinas, já que sua única função era operá-las. A linha de montagem estabelecia um ritmo cada vez mais acelerado, em busca da maior produtividade possível ${ }^{26}$.

Quanto ao fordismo e taylorismo, demonstra Ricardo Antunes:

Com o desenvolvimento do capitalismo industrial, experimentado especialmente pela indústria automobilística norte-americana do início do século XX, ocorre o florescimento e a expansão do taylorismo e do fordismo, que acabaram conformar o desenho da indústria e do processo de trabalho em escala planetária. Seus elementos centrais podem ser assim resumidos:

1. vigência da produção em massa, realizada por meio da linha de montagem e produção mais homogênea;

2. controle dos tempos e movimentos por meio do cronômetro taylorista e da produção em série fordista;

3. existência do trabalho parcelar e da fragmentação das funções;

4. separação entre a elaboração, cuja responsabilidade era atribuída à gerência científica, e a execução do processo de trabalho, efetivada pelo operariado no chão da fábrica;

5. existência de unidades fabris concentradas e verticalizadas. ${ }^{27}$

Pouco importava a mão de obra que seria utilizada, homem adulto, mulher ou criança, que tinha que existir era o trabalho mecânico, automático. Pensar não era

\footnotetext{
${ }^{25}$ HUBERMAN, Leo. História de riqueza do homem. Tradução de Waltensir Dutra: atualização e revisão técnica Marcia Guerra. 22ª rev e ampl. Rio de Janeiro: LTR, 2011, p. 89.

${ }^{26} \mathrm{O}$ fordismo foi muito bem ilustrado por Charles Chaplin em seu filme Tempos Modernos.

${ }^{27}$ ANTUNES, Ricardo. O continente do labor. São Paulo: Editora Boitempo, 2011, p. 22.
} 
necessário, era preciso tão somente mão de obra para ter contato com a máquina, ocasião demonstrada pelo historiador Geoffrey Blainey:

Um americano, ao descrever uma fiação de lã, em Yorkshire, em 1815, observou que aproximadamente 50 meninos e meninas estavam lá empregados, com horário de trabalho das 6 às 19 horas. No inverno, chegavam e saíam no escuro. A criança mais velha tinha no máximo 10 anos. Todas ficavam lambuzadas de poeira e gordura vindas de lá crua que manipulavam. A nova fábrica - ao contrário dos trabalhos rurais, como cuidar dos gansos e ordenhar as vacas - era um tirano que exigia a atenção das crianças o dia inteiro, mesmo quando estavam quase adormecendo de tão exaustas. ${ }^{28}$

Leo Huberman traz dados alarmantes quanto ao trabalho infantil utilizados nas industrias nesta época:

Crianças de menos de 16 anos trabalhavam em 96 das 129 famílias estudadas...metade delas tinha idade inferior a 12 anos. Trinta e quatro tinham 8 anos e menos, e doze tinham menos de 5 anos...chocante, não é? Pensar em crianças de dois ou três anos trabalhando! Será isso um relatório sobre o sistema doméstico entre os séculos XVI e XVIII? Na verdade não. Qual a época e o local das condições acima descritas? Época: agosto de 1934, Connecticut, Estados Unidos. ${ }^{29}$

Devido aos baixos salários, o trabalhador via-se quase que obrigado a trabalhar jornadas exaustivas que ensejavam acidentes de trabalho, número comparado as duas grandes guerras mundiais.

A igualdade concedida neste momento histórico deu-se tão somente na esfera legal, sendo que no espectro material inexistia, pois os cidadãos de fato, eram desiguais. E ainda, igualava em obrigações e deveres, pessoas que materialmente são distintas pela sua própria natureza como homens, mulheres e crianças.

As Revoluções Industriais ocasionaram uma mudança brutal na sociedade que perdura até a presente data, êxodo rural. Pessoas saíram do campo e foram para os grandes centros em busca de trabalho, ensejando o fenômeno da sociedade industrial.

A classe trabalhadora (dominada), que submetia-se as vontades da burguesia, trabalhando em condições desumanas, inclusive mulheres e crianças.

\footnotetext{
${ }^{28}$ BLAINEY, Geoffrey. Uma breve história do mundo. São Paulo: Editora Fundamento Educacional, 2010, p. 253.

${ }^{29}$ HUBERMAN, Leo. História de riqueza do homem. Tradução de Waltensir Dutra: atualização e revisão técnica Marcia Guerra. 22ª rev e ampl. Rio de Janeiro: LTR, 2011, p. 89.
} 
Devido as enormes jornadas de trabalho, o número de acidente de trabalho era alarmante (com morte do empregado), comparado as duas grandes guerras mundiais.

A situação criada pelas Revoluções Industriais acaba dando origem ao suporte fático para a relação de emprego, composta pelos requisitos: trabalho prestado por pessoa física, onerosidade, subordinação, habitualidade e pessoalidade, atualmente previstos no caso brasileiro, nos artigos $2^{\circ}$ e $3^{\circ}$, da Consolidação das Leis do Trabalho.

Pode-se afirmar que uma das bases do sistema capitalista de produção é a relação de emprego, pois de um lado oferta ao empregado uma determinada garantia que vai receber algum dinheiro amanhã para sua sobrevivência, e lado outro, permite ao empregador durante a jornada de trabalho ter o pleno controle sobre o trabalhador e assim retirar dele o máximo de energia, dedicação e principalmente: o lucro. Quanto ao surgimento da espécie empregatícia ${ }^{30}$, demonstra Maurício Godinho Delgado:

Contudo, é a espécie mais importante de relação de trabalho existente no sistema econômico e social capitalista. Por meio de relação de emprego é que o novo sistema emergente no século XVIII na Europa - Inglaterra, em particular - descobriu uma modalidade de conexão específica dos trabalhadores às necessidade organizacionais e produtivas do capital, sem as peculiaridades restritivas de cunho econômico, social, tecnológico e cultural das modalidades anteriormente dominantes na experiência histórica (escravidão e servidão). ${ }^{31}$

Outro problema existente nesta modalidade estatal, foi a exclusão de uma parcela da população, tendo em vista a representação de uma parte da população. A classe considerada como como povo-não-cidadão (formada por aprendizes, servos, trabalhadores e mulheres), era representada por uma outra parte dita como povocidadão (detentora dos meios de produção e homens). Esta exclusão, era sustentada pela falácia de que "o povo-cidadão, pelo seu preparo, representaria adequadamente os interesses e as vontades do povo-não-cidadão, tendo em vista que esta parcela populacional era movida pelas emoções, pelo partidarismo, pela ingenuidade ou pela

\footnotetext{
${ }^{30}$ Entende-se por relação de trabalho um gênero que abrange qualquer tipo de atividade prestada por pessoa física a favor de outra pessoa (seja pessoa física ou jurídica), quer seja, transformação da natureza de forma consciente e voluntária, formada por diversas espécies como relação de emprego, doméstico, rural, avulso, desportista, portuário, autônomo e etc.

${ }^{31}$ DELGADO, Maurício Godinho. A Relação de emprego e relações de Trabalho - a retomada do expansionismo do Direito Trabalhista. In DELGADO, Maurício Godinho et al (Coords). Constituição da república e direitos fundamentais: dignidade da pessoa humana, justiça social e direito do trabalho. São Paulo: LTr, 2012, p. 106.
} 
ignorância". ${ }^{32} \mathrm{Ou}$ seja, uma classe social decidia pela outra, e com isso a classe trabalhadora além de ser explorada, era também excluída politicamente.

Diante do verdadeiro abismo (exploração, dominação e exclusão de uma parte da população sobre a outra) que a liberdade e a igualdade causaram à sociedade, a Europa no final do século XIX ficou dominada por revoluções, movimentos socais que desejavam a concessão de direitos que de alguma forma ofertassem uma igualdade de fato, e assim a inclusão social da maior parte da população que até então era excluída.

Impulsionados por ideais socialistas e marxistas da Primeira Internacional de 1864 (conhecida inclusive como Primeira Internacional Socialista) os movimentos operários atingem níveis de descontentamento alarmante, abrangendo grande parte da Europa, gerando assim uma onda de greves. Na Alemanha e na França, durante o ano de 1868; na Bélgica, em 1869; na Áustria-Hungria, em 1870, na Rússia; na Itália, em 1871 e na Inglaterra entre 1871-1873.

\subsection{Do constitucionalismo social}

Diante da ocorrência destes movimento sociais, no século XX, surge o Estado Social de Direito (Welfare State ou o Estado do Bem Estar Social), tendo como principal característica a postura positiva estatal, procurando o bem estar social.

O Estado passou a ter uma interferência ativa - e não absenteísta - diante de seus jurisdicionados, sendo promotor de políticas sociais, interventor nas relações particulares, para de alguma maneira corrigir, ou diminuir o individualismo e a desigualdade.

Através do constitucionalismo social, o Estado passou a ter uma interferência ativa na vida dos jurisdicionados, sendo promotor de políticas sociais, interventor nas relações particulares, para de alguma maneira ser alcançada a igualdade material, o que para Robert Alexy, seria "o dever de tratamento desigual" ${ }^{33}$. Em síntese: através da concessão de direitos, caracterizados pela postura ativa do Estado, criava-se uma

\footnotetext{
${ }^{32}$ SAMPAIO, José Adércio Leite. Teoria da constituição e dos direitos fundamentais. Belo Horizonte: Del Rey, 2013, p. 65.

${ }^{33}$ ALEXY, Robert. Teoria dos direitos fundamentais. Tradução de Virgílio Afonso da Silva. $5^{\text {a }}$ edição alemã. São Paulo: Malheiros Editores, 2011, p. 409.
} 
desigualdade formal, para alcançar-se uma igualdade material (o que para muitos denomina-se de equidade).

Assim ensina Carlos Henrique Bezerra Leite:

Surge então, o chamado Estado Social, que é compelido a adotar políticas públicas destinadas à melhoria das condições de vida dos mais pobres, especialmente da classe trabalhadora, como forma de compensar as desigualdades originadas pelos novos modos de produção ${ }^{34}$.

Sintetiza ainda:

São características do Estado Social, o constitucionalismo social (México, 1917, e Alemanha, 1919), a função social da propriedade, a participação política dos trabalhadores na elaboração de ordem jurídica e o intervencionismo (dirigismo) estatal na economia mediante prestações positivas (status positivus) por meio de leis que criam direitos sociais. O Estado Social visa o estabelecimento da igualdade substancial (real) entre as pessoas, por meio de positivação de direitos sociais mínimos (piso vital mínimo ou mínimo existencial). ${ }^{35}$

Surgem então os direitos fundamentais da segunda dimensão, conhecidos como direito sociais, de cunho social, cultural e econômico, em busca da igualdade material. E daí surgem os direitos socais, que engloba a educação, saúde, alimentação, trabalho, moradia, lazer, segurança, previdência social e outros.

O Estado diante de seus jurisdicionados era sujeito direitos (credor) também de deveres (prestador), em busca de um bem estar social. Neste sentido ilustra Nadia Soraggi Fernandes:

Estes direitos fundamentais caracterizam-se, ainda hoje, por outorgarem, ao indivíduo, direitos a prestações sociais estatais, como assistência social, saúde, educação, trabalho, etc., além de abrangerem também as liberdades sociais como a liberdade de sindicalização, o direito de greve e o reconhecimento de direitos fundamentais aos trabalhadores, tais como o direito a férias e ao repouso semanal remunerado, a garantia de um salário mínimo, a limitação da jornada de trabalho, entre outras. ${ }^{36}$

\footnotetext{
${ }^{34}$ LEITE, Carlos Henrique Bezerra. Curso de direito processual do Trabalho. $9^{\mathrm{a}}$ ed. São Paulo: LTr, 2011, p.35.

${ }^{35}$ Idem, p.36.

${ }^{36}$ FERNANDES, Nadia Soraggi. Ação civil pública trabalhista: forma célere e efetiva de proteção dos direitos fundamentais dos trabalhadores. São Paulo: LTr 2010, p. 27.
} 
Neste contexto histórico surge também como direito social, o Direito do Trabalho, ramo jurídico que tem como objeto, a relação de emprego, conforme Jorge Luiz Souto Maior:

Pelo novo direito, o Direito do Trabalho, que chegou a marcar a passagem o modelo jurídico do Estado Liberal para o Estado Social, almeja-se, sobretudo, a elevação da condição social e econômica daquele que vende sua força de trabalho para o implemento da produção capitalista. ${ }^{37}$

\section{Ilustra Maurício Godinho Delgado:}

Neste momento surgem também o Direito do Trabalho e do Direito de Seguridade Social, "a partir de então, ganham status constitucional regras e princípios jurídicos antitéticos ao liberalismo prevalecente na fase originária das constituições, apontando direção muito distinta para o desenvolvimento do constitucionalismo ocidental. $^{38}$

O Direito do Trabalho, foi criado justamente para regulamentar a relação de emprego, que é a forma mais democrática de inclusão social do trabalhador e de distribuição de renda.

Inquestionavelmente que sendo a relação de emprego, um dos alicerces do sistema capitalista de produção, foi humanizada através do Direito do Trabalho, pois não poderia continuar sendo observada somente no aspecto patrimonial e em benefício único do empregador, como era feito durante o Estado Liberal.

Era necessária uma mudança, a busca por um equilíbrio entre as partes envolvidas em uma relação empregatícia. Assim também entende Jorge Luiz Souto Maior:

A venda da força de trabalho, que numa concepção capitalista pura, significa, meramente, a exploração do capital sobre o trabalho, ganha, com a inserção das normas trabalhistas, a inevitável repercussão de ordem obrigacional, que preserva o ser humano,

\footnotetext{
${ }^{37}$ MAIOR, Jorge Luiz Souto. Curso de direito do trabalho: a relação de emprego, volume II. São Paulo : LTr, 2008, p. 15.

${ }^{38}$ DELGADO, Maurício Godinho. Constituição da república, estado democrático de direito e direito d o trabalho. In DELGADO, Maurício Godinho et al (Coords). Constituição da república e direitos funda mentais: dignidade da pessoa humana, justiça social e direito do trabalho. São Paulo: LTr, 2012, p. 40.
} 
integra o trabalhador na sociedade e ao mesmo tempo fornece sustentação econômica as políticas públicas de interesse social. ${ }^{39}$

\section{Conforme ilustra Maurício Godinho Delgado:}

A centralidade do trabalho - e, em especial, sua forma mais articulada e comum no capitalismo, o emprego - torna-se o epicentro da organização da vida social e da economia. Percebe-se tal matriz a essencialidade da conduta laborativa como um dos instrumentos mais relevantes de afirmação do ser humano, quer no plano de sua própria individualidade, quer no plano de sua inserção familiar, social e econômica. ${ }^{40}$

Esta alteração ocorreu através do Direito do Trabalho, que oferta aos trabalhadores direitos destinados e próprios a relação de emprego, como: férias, jornada de trabalho, proteção contra acidente de trabalho e desemprego involuntário, $13^{\circ}$ salario, vedação a dispensa arbitrária ou sem justa causa, piso salarial e repouso semanal remunerado e previdência social.

As normas trabalhistas refletem a desigualdade que existe entre as partes envolvidas, enquanto que um ali trabalha para receber seu salário (e ter do que sobreviver), o outro aufere lucro; ao passo que o trabalhador vende sua força de trabalho (e sua liberdade), o empregador a compra, sendo o detentor de todos os meios de produção. É justamente o que Robert Alexy denomina de "uma razão suficiente para o dever de um tratamento desigual, então, o tratamento desigual é obrigatório". ${ }^{41}$

E assim é o que acontece no Direito do Trabalho, que é formado por um conjunto de normas de ordem pública (que desigualam os desiguais), que objetivam garantir ao empregado o patamar mínimo civilizatório, tese de Maurício Godinho Delgado, e assim efetivar o princípio da proteção (o norteador deste ramo jurídico).

A relação de emprego, pode ser considerada como espécie que oferta a melhor inclusão social ao empregado, tendo em vista que a ela é direcionada uma gama jurídica protetiva e ainda retira do trabalhador qualquer responsabilidade no negócio jurídico (já que o risco do empreendimento é do empregador).

\footnotetext{
${ }^{39}$ SOUTO MAIOR, Jorge Luiz. Curso de direito do trabalho: a relação de emprego, volume II. São Pa ulo: LTr, 2008, p. 15.

${ }^{40}$ DELGADO, Maurício Godinho. Capitalismo, trabalho e emprego: entre o paradigma de destruição e o caminhos de reconstrução. São Paulo: LTr 2005, p. 29.

${ }^{41}$ ALEXY, Robert. Teoria dos direitos fundamentais. Tradução de Virgílio Afonso da Silva. $5^{\mathrm{a}}$ edição alemã. São Paulo: Malheiros Editores, 2011,p. 409.
} 
A parcela da população que é despossuída de capital não possui outro caminho a não ser a venda da sua mão de obra (sua liberdade), para em contraprestação receber o que lhe é devido (dinheiro), e assim ter sua sobrevivência garantida. E através da relação empregatícia esta "troca" é a que oferta mais direitos ao trabalhador e lado outro garante ao empregador a segurança jurídica devida.

Portanto, a relação de emprego pode ser considerada até mesmo como uma forma de manutenção do sistema capitalista de produção, concedendo a ambas as partes, direitos que os tornam satisfeitos. E assim, tem-se que "inicialmente, de certo modo, a legislação trabalhista significou uma estratégia para impulsionar e manter a exploração capitalista sobre o trabalho alheio". ${ }^{42}$

Destaca-se ainda que no Estado Social, foi alterado até mesmo a posição do Estado (juiz), que durante o Estado Liberal se resumia a respeitar tão somente o princípio da legalidade, através da conhecida técnica do positivismo, la bouche $d u$ droit. A partir do constitucionalismo social, o julgamento de uma lide deveria ser feito através de métodos mais sofisticados como a análise teleológica, a sistêmica, constitucional e a histórica, capazes de olvidar os fins socais da lei e o bem comum, o que nos presentes dias, está previsto no art. $5^{\circ}$, da Lei de Introdução às Normas do Direito Brasileiro.

Conforme se percebe, o Direito do Trabalho, possui como fontes materiais (revoltas, revoluções e movimentos sociais), originadas por variações sociais, políticas, culturais e econômicas. Por isso, este ramo jurídico deve ser considerado embrionariamente um direito coletivo. Sendo assim, proteger o direito coletivo do trabalho é necessariamente fortalecer o direito individual do trabalho. Os direitos trabalhistas foram conquistados através de muitas lutas dos trabalhadores e dos sindicatos, perdas, idas e vindas, sendo fruto de muito sofrimento.

Conforme verifica José Roberto Freire Pimenta pertinente à natureza coletiva (greves, revoltas, revoluções, movimentos sociais e políticos) do Direito do Trabalho:

Com efeito, é incontroverso que o próprio Direito do Trabalho sempre teve, desde sua origem, uma razão de ser a uma dimensão fundamentalmente social e coletiva, pois nasceu dos conflitos

\footnotetext{
${ }^{42}$ MAIOR, Jorge Luiz Souto. Curso de direito do trabalho: a relação de emprego, volume II. São Paulo : LTr, 2008, p. 15.
} 
coletivos entre as empresas capitalistas e seus empregados, de um lado, e o conjunto de trabalhadores, do outro. ${ }^{43}$

No mesmo sentido demonstra Maria Cecília Máximo Teodoro:

A industrialização propiciou o surgimento do direito do trabalho da mesma forma que possibilitou o desenvolvimento da união coletiva. Mesmo porque existe uma verdadeira relação de causa e efeito entre os dois. Pode-se dizer também que o direito do trabalho surgiu da união e organização dos trabalhadores ${ }^{44}$.

E ainda:

Portanto, foram as lutas dos trabalhadores explorados nas grandes indústrias, somadas ao Estado social, que intervinha na esfera privada e era de índole promocional, que propiciaram maior regulamentação dos direitos trabalhistas ${ }^{45}$.

O Direito do Trabalho tem a sua criação na direção de reconstrução da sociedade que tinha sido esfacelada pelo capitalismo desorganizado, ao final da Segunda Guerra Mundial, servindo como premissa para os demais direitos sociais. Essa reconstrução seria então coletiva e não individual. A sociedade a partir de então passou a ser vista pela ótica da coletividade e não na individualidade.

\subsection{Do constitucionalismo democrático}

Muito embora os direitos fundamentais (principalmente) os sociais estivessem previstos constitucionalmente, na prática não estavam sendo efetivados. Com isso passaram então a ser considerados como meras promessas estatal.

Assim, em meados do século XX é criado o Estado Democrático, que dentre seus motivos ensejadores, era a busca pela efetivação dos direitos fundamentais anteriores.

\footnotetext{
${ }^{43}$ PIMENTA, José Roberto Freire. A tutela metaindividual dos direitos trabalhistas: uma exigência constitucional. In: PIMENTA, José Roberto Freire et al (Coords). Tutela metaindividual trabalhista. São Paulo: LTr, 2009, p. 24.

${ }^{44}$ TEODORO, Maria Cecília Máximo. O juiz ativo e os direitos trabalhistas. $1^{a}$ ed. São Paulo: LTr, 20 11, p. 73 .

${ }^{45}$ Idem, p. 74.
} 
O ser humano na democracia é a "grundnorm (basic norm) ${ }^{46}$ do ordenamento jurídico, que deve existir justamente para promover o bem estar da pessoa, passando até mesmo a ofertar novas diretrizes constitucionais.

Para José Joaquim Gomes Canotilho, o Estado Democrático seria até mesmo uma evolução do Estado de Direito:

O Estado constitucional é mais do que Estado de direito. O elemento democrático não foi apenas introduzido para travar o poder (to check the power); foi também reclamado pela necessidade de legitimação do mesmo poder (to legitimize State power). Se quisermos um Estado constitucional assente em fundamentos não metafísicos, temos de distinguir claramente das coisas: (1) uma é de legitimidade do direito, dos direitos fundamentais e do processo de legitimação no sistema jurídico; (2) outra é a de legitimidade de uma ordem de domínio político e da legitimação do exercício do poder político. O Estado impolítico do Estado direito não dá resposta a este último problema: donde vem o poder. Só o princípio da soberania popular segundo o qual todo o poder vem do povo assegura e garante o direito à igual participação na formação democrática da vontade popular. Assim, o princípio da soberania popular concretizado segundo procedimentos juridicamente regulados serve de charneira entre o Estado de direito e o Estado de direito democrático. Alguns autores avançam mesmo a ideia de democracia com valor (e não apenas como processo), irresistivelmente estruturante de uma ordem constitucional democrática. ${ }^{47}$

Para Luís Roberto Barroso, "constitucionalismo significa, em essência, limitação do poder e supremacia de lei (Estado de direito, rule of law, Reschtsstaat). Democracia, por sua vez, em aproximação sumária, traduz-se em soberania popular e governo da maioria". ${ }^{48}$

No Brasil o marco da democracia é a Constituição da República de 1988, conhecida popularmente como Carta Cidadã, que traz expressamente a forma federativa; o Estado Democrático de Direito; e a dignidade da pessoa humana e o trabalho como fundamentos da República.

\footnotetext{
${ }^{46}$ É um conceito da Teoria Pura do Direito criado por Hans Kelsen, jurista e filósofo legal. Kelsen usou essa palavra para designar a norma básica, ordem ou regra que forma uma base subjacente para um sistema legal. A teoria baseia-se em uma necessidade de encontrar um ponto de origem para todas as leis, em que a lei básica e a constituição pode ganhar a sua legitimidade (semelhante ao conceito de primeiros princípios).

${ }^{47}$ CANOTILHO, José Joaquim Gomes. Direito constitucional e teoria da constituição. $7^{\mathrm{a}}$ ed, $13^{\mathrm{a}}$ reimpressão. Coimbra: Edições Almedina, 1941, p. 100.

${ }^{48}$ BARROSO. Luís Roberto. A dignidade da pessoa humana no direito constitucional comparado: a construção de um conceito jurídico à luz da jurisprudência mundial; tradução Humberto Laport de Mello. $2^{\mathrm{a}}$ reimpressão. Belo Horizonte: Editora Fórum, 2013, p.107.
} 
Conforme demonstra Ingo Wolfgang Sarlet:

No que diz com o seu conteúdo, cuida-se de documento acentuadamente compromissário, plural e comprometido com a transformação da realidade, assumindo, portanto, um caráter fortemente dirigente, pelo menos quando se toma como critério o conjunto de normas impositivas de objetivos e tarefas em matéria econômica, social, cultural e ambiental contidos no texto constitucional, para o que bastaria ilustrar com o exemplo dos assim chamados objetivos fundamentais elencados no art. $3^{\circ}$. Tanto o Preâmbulo quanto o título dos Princípios Fundamentais são indicativos de uma ordem constitucional voltada ao ser humano e ao pleno desenvolvimento da sua personalidade, bastando lembrar que a dignidade do ser humano, pela primeira vez na história constitucional brasileira, foi expressamente guindada (art. $1^{\circ}$, III, da $\mathrm{CF}$ ) à condição de fundamento do Estado Democrático de Direito brasileiro, por sua vez também como tal criado e consagrado no texto constitucional. Não é a toa, portanto, que o então Presidente da Assembleia Nacional Constituinte, Deputado Ulysses Guimarães, por ocasião da solenidade de promulgação da Constituição, batizou a Constituição de 1988 de Constituição Coragem e Constituição Cidadã, lembrando que, diferentemente das Constituições anteriores, a Constituição inicia com o ser humano. ${ }^{49}$

$\mathrm{Na}$ democracia o poder emana do povo, tendo em vista que seu epicentro é o ser humano. Quanto à estrutura básica deste modelo estatal, demonstra Maurício Godinho Delgado:

O conceito inovador de Estado Democrático de Direito, como dito, funda-se em um inquebrantável tripé conceitual: pessoa humana, com sua dignidade; sociedade política, concebida como democrática e includente; sociedade civil, também concebida como democrática e includente. ${ }^{50}$

O Estado Democrático possui alguns princípios que lhe são próprios: (i) da dignidade do ser humano; (ii) da participação popular nas decisões políticas e públicas; (iii) da inclusão social; (iv) do neoconstitucionalismo ${ }^{51} \mathrm{e}(\mathrm{v})$ das garantias processuais e da máxima efetividade dos direitos fundamentais.

\footnotetext{
49 SARLET, Ingo Wolfgang; MARINONI, Luiz Guilherme; MITIDIERO. Curso de direito constitucional. $2^{\mathrm{a}}$ ed. São Paulo: Editora Revista dos Tribunais, 2013, p. 256.

${ }^{50}$ DELGADO, Maurício Godinho. Constituição da república, estado democrático de direito e direito do trabalho. In DELGADO, Maurício Godinho et al (Coords). Constituição da república e direitos fundamentais: dignidade da pessoa humana, justiça social e direito do trabalho. São Paulo: LTr, 2012, p. 41.

${ }^{51}$ Ideia defendida por Luis Roberto Barroso e também por Pietro Perlingieri, Daniel Sarmento e Ricardo Guastini.
} 
A sociedade na democracia, é caracterizada pela globalização; formação de blocos econômicos e sociais; internacionalização da produção, até mesmo de mão-deobra e pela terceira revolução industrial (que abrange os meios de informática, mecanismos robóticos); massificação e multidiversidade das nações e uma capacidade de rápida transformação (tanto política, cultural e jurídica).

Esta alteração multifacetária é consequência imediata da mudança do sistema capitalista de produção, conforme assevera Erich Fromm:

Há outras necessidades que diferem por exemplo, entre o capitalismo do século XIX e o contemporâneo. O primeiro preocupava-se ainda principalmente com a acumulação de capital, e, portanto com a necessidade de poupar; tinha de fortificar a disciplina e estabilidade pelos princípios autoritários na família, religião, indústria, Estado e Igreja. O caráter social da classe média do século XIX, era, sob muitos aspectos, precisamente o que podemos considerar uma tendência ao entesouramento. Abstenção do consumo, poupança e respeito pela autoridade foram não apenas virtudes, mas também satisfações para o membro médio da classe média; sua estrutura de caráter levou-o a fazer aquilo que para as finalidades de seu sistema é totalmente diferente. A economia hoje baseia-se não na restrição do consumo, mas em seu desenvolvimento máximo. Nossa economia enfrentaria uma crise severa se o povo - os trabalhadores e a classe média - não despendesse maior parte de sua renda no consumo, poupando-a ao invés disso. $\mathrm{O}$ consumo tornou-se não apenas o objetivo apaixonado da vida da maioria das pessoas, mas também uma virtude. O consumidor moderno - o homem que compra a prazo - teria parecido um gastador irresponsável e imoral ao seu avô, tal como este há de parecer um avarento para seu neto. O caráter social do século XIX só se encontra hoje nas camadas mais atrasadas da Europa e América do Norte; ele pode ser definido como tendo por principal objeto a posse, enquanto o caráter social do século XX tem por finalidade o $u s o^{52}$.

Quanto ao neoconstitucionalismo, destaca-se é uma inovadora forma de interpretação do ordenamento jurídico, pautado pela supremacia da ordem constitucional sobre todos os ramos do direito, constituindo até mesmo como filtro das normas infraconstitucionais.

Nesta nova forma de interpretação, a constituição considerada como instrumento superior do ordenamento jurídico nacional, passa a ser analisada sob o enfoque do pós-positivismo, ocasião em que as normas constituem um gênero,

\footnotetext{
${ }^{52}$ FROMM, Erick. Meu encontro com Marx e Freud. $7^{\mathrm{a}}$ ed. São Paulo: Zahar Editores, 1962. p. 79.
} 
dividido entre duas espécies: regras e princípios. Quanto aos novos contornos constitucionais, sintetiza Luís Roberto Barroso:

Sedimentado o caráter normativo das normas constitucionais, o Direito contemporâneo é caracterizado pela passagem da Constituição para o centro do sistema jurídico, onde desfruta não apenas da supremacia formal que sempre teve, mas também de uma supremacia material, axiológica. Compreendida como uma ordem objetiva de valores e como um sistema aberto de princípios e regras, a Constituição transforma-se no filtro através do qual se deve ler todo o direito infraconstitucional. Esse fenômeno tem sido designado como constitucionalização do Direito, uma verdadeira mudança da paradigma que deu novo sentido e alcance a ramos tradicionais e autônomos do Direito, como o civil, o administrativo, o penal e o processual. ${ }^{53}$

O pós-positivismo é uma evolução do positivismo (interpretação literal e seca da lei, através da técnica da subsunção), conforme ilustra Robert Alexy:

O modelo puro de regras fracassa em todas as três formas de regulação dos direitos fundamentais consideradas acima. É possível supor que esse modelo é insuficiente também para outras formas de regulação encontradas na Constituição alemã. $\mathrm{O}$ modelo puro de princípios foi rejeitado porque ele não leva a sério as regulações adotadas pela Constituição. Quando duas firmas puras e antagônicas não são aceitáveis, deve-se considerar a possibilidade de uma forma mista ou combinada, ou seja, de um modelo combinado. Um tal modelo é modelo de regras e princípios, que surge de ligação entre um nível de princípios e um nível de regras. ${ }^{54}$

No neoconstitucionalismo o princípio da dignidade da pessoa humana é utilizado como norteador da intepretação da ordem constitucional que irradia seus efeitos a todo o panorama infraconstitucional. A dignidade do ser humano passa a ser o princípio norteador de todo o arcabouço jurídico.

Em linhas sintéticas e gerais pode-se dizer que o modelo de intepretação denominado de neoconstitucionalismo é formado pela junção de três fatores: (i) elevação da Constituição ao status de direcionador dos ramos infraconstitucionais que devem ser efetivados conforme a Carta Magna; (ii) as normas são consideradas como

\footnotetext{
${ }^{53}$ BARROSO. Luís Roberto. Curso de direito constitucional contemporâneo: os conceitos fundamentais e a construção do novo modelo. $4^{a}$ ed. São Paulo: Saraiva, 2013, p. 109.

${ }^{54}$ ALEXY, Robert. Teoria dos direitos fundamentais. Tradução de Virgílio Afonso da Silva. $5^{a}$ edição alemã. São Paulo: Malheiros Editores, 2011,p. 135.
} 
um gênero, formado pelas regras e princípios e (iii) o princípio da dignidade da pessoa humana é a grundnorm (basic norm) do ordenamento jurídico.

O figura do Estado na democracia desempenha uma função de fomentador de participação pública no processo de reconstrução de um novo projeto de sociedade, em uma perspectiva humanística e com obrigação de observar a população de forma massiva, mas ao mesmo tempo diversificada.

Neste contexto surgem os direitos fundamentais de terceira dimensão, denominados como direitos coletivos lato sensu, um gênero que engloba três espécies, sendo elas: direito difusos, coletivos stricto sensu e individuais homogêneos, com o propósito de efetivação dos direitos constitucionalmente assegurados (que não estavam sendo cumpridos).

Fazendo um quadro comparativo entre a transição dos Estado Liberal para o Estado Social de Direito, e este para o Estado Democrático, percebe-se que a primeira transição deu-se por questões quantitativas, foram criados "novos" direitos como saúde, trabalho, educação e outros (fundamentais da segunda dimensão). Na segunda transição pode-se dizer que os direitos criados (de terceira dimensão), foram na perspectiva qualitativa, como pano de fundo. Ou seja, correspondem a modos, viés, instrumentos de como se fazer cumprir, efetivar os direitos constituídos nas dimensões anteriores.

Ainda no Estado Democrático de Direito, surgem os direitos fundamentais da quarta e quinta dimensões - temas ainda recentes e não pacíficos na doutrina que conta com nomes como Paulo Bonavides, José Alcebíades de Oliveira Junior, Ingo Wolfgang Sarlet e José Adércio Leite Sampaio.

Quanto aos direito da quarta dimensão, pode-se dizer que são fruto da transformação mundial ocasionada pela globalização, internacionalização da produção e da mão de obra, sustentabilidade, novas ferramentas tecnológicas e pela formação dos blocos econômicos.

Até a presente data não há uma uniformidade de quais seriam da quarta dimensão, sendo uma temática ainda em construção. Mas, é certo que em linhas gerais, pode-se dizer que valorizam e protegem ainda mais a grundnorm do Estado 
Democrático, tanto na órbita individual, como coletiva, "sendo um direito atribuído aos povos e nações, e não propriamente ao indivíduo-pessoa". ${ }^{55}$

Estes novos direito, objetivam a universalização institucional dos direitos fundamentais na perspectiva sustentável e futurológica, abrangendo direitos "ambiental, cultural, democracia direta (participativa), à informação e o pluralismo" 56, para que seja alcançada uma convivência pacífica entre os povos, através da democracia globalizada.

Conforme Paulo Bonavides:

São direitos da quarta geração o direito à democracia, o direito à informação e o direito ao pluralismo. Deles depende a concretização da sociedade aberta do futuro, em sua dimensão de máxima universalidade, para a qual parece o mundo inclinar-se no plano de todas as relações de convivência. ${ }^{57}$

Para José Adércio Leite Sampaio:

Não há um consenso em torno da existência e conteúdo dos direitos da quarta geração. Seriam, para uns desdobramento da terceira geração, designadamente, os direitos coletivos ou solidários, como a paz, o meio ambiente saudável e a proteção da sobrevivência da cultura indígena, haveriam de compor uma geração à parte, deixando o direito ao desenvolvimento sem qualificativos de sustentabilidade na geração anterior. Seriam todos eles direitos relacionados à necessidade de garantia da vida permanente e saudável na e da Terra, compondo, genericamente, os direitos intergeracionais a um vida saudável ou a um ambiente equilibrado, como se afirmou na Carta da Terra ou Declaração do Rio de 1992, repetindo-se no Manifesto de Tenerife; associados à proteção da cultura, conforme dispõe a cláusula 9 do Documento Final do Encontro de Ministros da Cultura do Movimento dos Países Não Alinhados, realizado em Medellin, Colômbia, entre os dias 3 e 5 de setembro de 1997. Reconhecem-se os direitos à vida das gerações futuras, a uma vida saudável e em harmonia com a natureza e ao desenvolvimento sustentável (tese do direitos ambientaisculturais). ${ }^{58}$

Demonstra Ingo Wolfgang Sarlet:

\footnotetext{
55 SARLET, Ingo Wolfgang; MARINONI, Luiz Guilherme; MITIDIERO. Curso de direito constitucional. $2^{\mathrm{a}}$ ed. São Paulo: Editora Revista dos Tribunais, 2013, p. 276.

${ }^{56}$ BONAVIDES, Paulo. Curso de direito constitucional. $28^{\mathrm{a}}$ ed. São Paulo: Malheiros Editores, 2013, p. 590.

${ }^{57}$ Idem, p. 590.

${ }^{58}$ SAMPAIO, José Adércio Leite. Teoria da constituição e dos direitos fundamentais. Belo Horizonte: Del Rey, 2013, p. 575.
} 
Contudo há que se referir no âmbito do direito brasileiro, a posição de Paulo Bonavides, que, com a sua peculiar originalidade, se posiciona favoravelmente ao reconhecimento da existência de uma quarta dimensão, sustentando que esta é o resultado da globalização dos direitos fundamentais, no sentido de uma universalização no plano institucional, que corresponde, na sua opinião a derradeira fase de institucionalização do Estado Social. ${ }^{59}$

Também são considerados como da quarta dimensão os direitos: à bioética (manipulação genética); à biotecnologia e a bioengenharia, impondo assim limites aos avanços da ciência; à verdade sobre as violações de direitos humanos no passado; à efetiva participação cidadã; à comunicação ou a comunicar-se tendo em vistas as mudanças tecnológicas (virtuais); das mulheres; humanitários (abrangendo os refugiados); de aspiração (autorealização) e psicoespirituais. ${ }^{60}$

Os direitos fundamentais da quarta dimensão, possuem aspectos de ordem material, social, político e psicológico para de alguma forma fomentar um mundo mais humanizado e sustentável. Parte da doutrina entende ainda que a "titularidade desses direitos é coletiva: a família, o povo, a nação ou a própria humanidade como um todo". ${ }^{61}$

Muito embora não exista consenso quanto aos direitos fundamentais da quarta dimensão, já existe corrente que defende a existência dos direitos fundamentais da quinta dimensão, que assim como a geração anterior, também encontra-se em fase incipiente.

Os direitos fundamentais da quinta dimensão "se logra, em termos constitucionais, mediante a elevação autônoma e paradigmática da paz." 62

Demonstra Paulo Bonavides:

Epicentro, portanto dos direitos de mais recente dimensão, a paz de levante, desse modo, a uma culminância jurídica que a investe no mesmo grau de importância e ascendência que teve e tem o desenvolvimento enquanto direito da terceira geração. ${ }^{63}$

\footnotetext{
59 SARLET, Ingo Wolfgang; MARINONI, Luiz Guilherme; MITIDIERO. Curso de direito constitucional. $2^{\mathrm{a}}$ ed. São Paulo: Editora Revista dos Tribunais, 2013, p. 276.

${ }^{60}$ Idem, p. 578.

${ }^{61}$ BONAVIDES, Paulo. Curso de direito constitucional. 28 ed. São Paulo: Malheiros Editores, 2013, p. 590.

${ }^{62}$ SAMPAIO, José Adércio Leite. Teoria da constituição e dos direitos fundamentais. Belo Horizonte: Del Rey, 2013, p. 603.

${ }^{63}$ BONAVIDES, Paulo. Curso de direito constitucional. 28 ed. São Paulo: Malheiros Editores, 2013, p. 590 .
} 
Encerra-se este tópico alertando que inexiste qualquer sobreposição de um direito fundamental sobre o outro, e sim um aprimoramento, uma soma, entre estes direitos, vez que, os direitos de todas as dimensões se completam, para atingir um único objetivo: a proteção ao ser humano. ${ }^{64}$ Todos os direitos que forem necessários para satisfazer as condições básicas e vitais do ser humano devem ser acompanhados e resguardados pelos direitos humanos.

Assim leciona Gabriela Neves Delgado:

Sob o prisma da história política, social, cultural e econômica, podese afirmar que o Estado Democrático de Direito é o mais evoluído na dinâmica dos Direitos Humanos, por fundar-se em critérios de pluralidade e de reconhecimento universal de direitos. ${ }^{65}$

\subsubsection{Do transconstitucionalismo}

Através do surgimento dos direitos fundamentais da quarta e quinta dimensões surge a teoria do transconstitucionalismo ${ }^{66}$, que alterou o entendimento de que a Constituição da maneira isolada e estanque seria capaz de ofertar aos jurisdicionados de uma nação todas as respostas jurídicas necessárias.

O transconstitucionalismo esta relacionado diretamente ao conteúdo das Constituições, fazendo com que tratados e convenções internacionais sejam incorporados à orbita constitucional nacional. Este novo formato constitucional é resultado do "pluralismo de ordenamentos superiores" "abertura material do catálogo dos direitos fundamentais"68).

Para Marcelo Neves:

O transconstitucionalismo é o entrelaçamento de ordens jurídicas diversas, tanto estatais como transnacionais, internacionais e supranacionais, em torno dos mesmos problemas de natureza constitucional. Ou seja, problemas de direitos fundamentais e limitação de poder que são discutidos ao mesmo tempo por tribunais de ordens diversas. ${ }^{69}$

\footnotetext{
${ }^{64}$ Justamente por não existir uma superioridade entre os direitos fundamentais que o autor deste artigo coaduna com a terminologia de dimensão e não geração de direitos fundamentais.

${ }^{65}$ DELGADO, Gabriela Neves. Direito fundamental ao trabalho digno. São Paulo: LTr, 2006, p. 49.

${ }^{66}$ Expressão utilizada por Marcelo Neves.

${ }^{67}$ Expressão utilizada por José Joaquim Gomes Canotilho.

${ }^{68}$ Terminologia usada por Ingo Wolfgang Sarlet.

${ }^{69}$ NEVES, Marcelo. Transconstitucionalismo. São Paulo: Editora Martins Fontes, 2009.
} 
Inclusive José Joaquim Gomes Canotilho coloca os direitos internacionais e comunitários no mesmo patamar dos direitos constitucionais:

A Constituição não dá resposta a todos os problemas relacionados com as fontes de direito. Como em qualquer sistema dotado de complexidade, existem problemas relacionados com a unidade do sistema jurídico e com a articulação das várias fontes de direito. Em geral, dizia-se e ensinava-se que a Constituição representava o vértice de um sistema de normas construído sob a forma de pirâmide jurídica que, na sua globalidade, formava a ordem jurídica. Este modelo não se tem hoje a virtualidade suficiente para captar o relevo jurídico do direito internacional e do direito comunitário. Não há um vértice com uma norma superior; no estalão superior situam-se vários ordenamentos superiores - ordenamento constitucional, ordenamento internacional e ordenamento comunitário - cuja articulação oferece inequívoca dificuldades, sobretudo quando qualquer desses documentos disputa a supremacia normativa ou, pelo menos, a aplicação preferente das suas normas e princípios. $^{70}$

Quanto ao tema, demonstra Luís Roberto Barroso:

A tradicional percepção da Constituição como documento supremo, expressa na imagem do vértice de uma pirâmide, enfrenta o desafio doutrinário de um mundo onde convivem inúmeras fontes normativas superiores. Todas aspiram à primazia ou, no mínimo, à igualdade hierárquica, e dentre elas se incluem, além do próprio direito constitucional, também o direito internacional e o direito comunitário. Nesse cenário, foi assinado, ao fim de 2004, o tratado que estabelece uma Constituição para a Europa. Todavia, sua não aprovação em referendos realizados na França e na Holanda (Países Baixos), no primeiro semestre de 2005, lançou incertezas e adiou o início de sua vigência. ${ }^{71}$

Este novo formato constitucional representa nada menos do que a insuficiência do modelo criado no Século XVIII, quando ensejou o Estado de Direito, que colocava a Constituição isolada de qualquer interferência internacional e comunitária, devendo este diploma refletir tão somente a realidade social de uma nação. Este isolamento ocorria até mesmo pelo fato daquele momento histórico o mundo não ser globalizado, os países não eram interdependentes uns dos outros e inexistiam os blocos

\footnotetext{
${ }^{70}$ CANOTILHO, José Joaquim Gomes. Direito constitucional e teoria da constituição. $7^{\mathrm{a}}$ ed, $13^{\mathrm{a}}$ reimpressão. Coimbra: Edições Almedina, 1941, p. 695.

${ }^{71}$ BARROSO. Luís Roberto. Curso de direito constitucional contemporâneo: os conceitos fundamentais e a construção do novo modelo. $4^{a}$ ed. São Paulo: Saraiva, 2013, p. 110.
} 
econômicos. Os países eram isolados e não estabeleciam relações com outras nações como realiza hoje em dia, e por isso estabeleciam suas próprias regras.

Muito embora a elaboração de uma Constituição única (monismo) para os países membros da Europa não tenha sido aprovada e adotada até a presente data, percebe-se claramente a tendência desta ideia materializar-se. É que na presente data alguns países como a Áustria, já adota inclusive o dualismo constitucional, tendo em vista que os direitos estabelecidos pela Comunidade Europeia encontram-se hierarquicamente junto aos princípios constitucionais do respectivo país, acima inclusive das regras constitucionais, servindo a alicerce para todo o ordenamento infraconstitucional.

Atualmente na Europa os direitos previstos pela Comunidade Europeia, possuem status de supranacionalidade, efetivando e garantindo a aplicação uniforme das políticas previstas no processo de integração entre os Estados.

O Direito Comunitário Europeu é um sistema jurídico singular, que não pode ser confundido com o direito interno dos países, pois suas normas são editadas por órgãos de natureza comunitária e têm aplicabilidade imediata nas ordens jurídicas internas desses Estados.

José Joaquim Gomes Canotilho leciona inclusive que havendo coalisão entre as normas do direito comunitário europeu e o direito interno, prevalece aquela perante esta:

A hierarquia e o valor do direito comunitário perante o direito interno dos estados membros da União Europeia continua um problema em aberto. Continua em aberto porque faltam regras expressas sobre conflitos de normas e porque é problemática a resposta à questão de saber se e em que medida a ordem jurídica interna e a ordem jurídica comunitária são ordens jurídicas autônomas e equi-ordenadas. A partir de várias normas constitucionais como as referentes à cláusula europeia (art.7.\%/5), à cláusula de integração europeia (art. 7.\%), à vigência directa na ordem jurídica interna de normas emanadas de órgãos competentes de organizações internacionais (art. 8.\%/3), à forma de transposição de directivas comunitárias (arts. 112.\%9), a doutrina e jurisprudência destilaram alguns princípios de orientação. Adiante desenvolver-seá este ponto. Registre-se, porém, que o princípio de integração (artigo 7.\%: exercício em comum dos poderes necessários à construção da união europeia) e o principio da capacidade funcional da Comunidade apontam para a preferência de aplicação do direito europeu em relação ao direito interno dos estados membros. Isso significa que os preceitos primários e secundários do direito comunitário tem aplicação imediata e preferente (preemption) relativamente às normas contrárias do direito interno. Os limites 
desta aplicação preferente resultarão de normas constitucionais relacionadas com os direito fundamentais de cidadãos portugueses e com dimensões inelimináveis da estabilidade republicana portuguesa. $^{72}$

E quanto a coalisão entre os direitos internacionais e o direito interno, demonstra o doutrinador português, "a radiação de um jus cogens internacional cuja observância se impõe como dever imperativo dos Estados":

\begin{abstract}
Em relação ao esquema referencial entre as normas de direito interno de valor legislativo e as normas de direito internacional, a generalidade da doutrina tem-se inclinado no sentido de interpretar $\mathrm{o}$ art. $8^{\circ}$, da lei fundamental a favor da prevalência do direito internacional tanto sobre o direito interno anterior como sobre o direito interno posterior, embora discutido o fundamento e o preciso alcance dessa prevalência. ${ }^{73}$
\end{abstract}

No transconstitucionalismo, as normas constitucionais comunicam-se com o direito internacional e com o direito comunitário, formando um campo normativo no sentido de ofertar ao ser humano uma gama maior de direitos fundamentais (humanos) objetivando sua plena satisfação.

Fazendo uma leitura histórica quanto ao constitucionalismo brasileiro, percebe-se que o transconstitucionalismo encontra-se presente no ordenamento jurídico nacional desde a Constituição de 1891 (art. 78), que já ofertava a abertura do catálogo constitucional dos direitos fundamentais, passando depois pelas Cartas Magnas de 1934 (art. 114), 1937 (art. 123), 1946 (art.144), 1967 (art. 150) e na Emenda 1/69 (art. 153), tendo sido inspirada na IX Emenda da Constituição dos Estados Unidos. ${ }^{74}$

Atualmente no Brasil, a sistemática da abertura material do catálogo dos direitos fundamentais é regulamentado em dois parágrafos do artigo $5^{\circ}$, da Constituição de 1988.

Prevê o parágrafo $2^{\circ}$, do art. $5^{\circ}$, da Constituição da República:

Os direitos e garantias expressões nesta Constituição não excluem outros decorrentes do regime e dos princípios por ela adotados, ou

\footnotetext{
${ }^{72}$ CANOTILHO, José Joaquim Gomes. Direito constitucional e teoria da constituição. $7^{\mathrm{a}}$ ed, $13^{\mathrm{a}}$ reimpressão. Coimbra: Edições Almedina, 1941, p. 695.

${ }^{73}$ Idem, p. 695.

${ }^{74}$ SARLET, Ingo Wolfgang; MARINONI, Luiz Guilherme; MITIDIERO. Curso de direito constitucional. $2^{\text {a }}$ ed. São Paulo: Editora Revista dos Tribunais, 2013, p. 281.
} 
dos tratados internacionais em que a República Federativa seja parte.

Quanto a expressão tratados internacionais utilizada na norma ut supra, imperioso trazer à baila os ensinamentos de Ingo Wolfgang Sarlet:

A despeito da falta de precisão terminológica e da diversidade de expressões encontradas no direito constitucional positivo, onde não se verifica critério uniforme de distinção entre as espécies de normas internacionais, existe uma certa unanimidade no seio da doutrina no sentido de que a expressão tratados internacionais engloba diversos tipos de instrumentos internacionais, cuidando-se, de portanto, de expressão genérica, em relação à qual as convenções e os pactos (apenas para citar alguns dos mais importantes) são espécies. ${ }^{75}$

O parágrafo $3^{\circ}$, do artigo $5^{\circ}$ que foi introduzido na Carta Magna através Emenda Constitucional 45/2004, tratou de efetivar e valorizar ainda mais a abertura material do catálogo dos direitos fundamentais, estabelecendo:

Os tratados internacionais sobre direitos humanos que forem aprovados, em cada Casa do Congresso Nacional, em dois turnos, por três quintos dos votos dos respectivos membros, serão equivalentes às emendas constitucionais.

Sendo assim, pode-se considerar a vigente Carta Constitucional brasileira como um documento de tipologia não fechada, preparado para acompanhar as transformações no mundo contemporâneo e assim introduzir formalmente ao ordenamento jurídico nacional novos direitos progressistas, capazes de ofertar aos jurisdicionado um melhor padrão de vida em todos os sentidos, sempre reconhecendo o ser humano como centro convergente.

A Emenda Constitucional 45/2004, que ensejou a redação do parágrafo $3^{\circ}$, do artigo $5^{\circ}$, da Constituição deve ser considerada como um marco teórico brasileiro quanto a incorporação dos tratados internacionais de direitos humanos no ordenamento jurídico brasileiro, através de uma simples comparação de dois julgados do Colendo Supremo Tribunal Federal, RHC 79.785 e o RE 466.343, que tratavam sobre o mesmo tema: a legitimidade jurídica da prisão civil do depositário infiel.

No julgamento do RHC 79.785, em 29.03.2000, ficou decidido que os tratados internacionais de direitos humanos ratificados pelo Brasil, encontravam-se no mesmo

\footnotetext{
${ }^{75}$ Idem, p. 281
} 
nível que as leis ordinárias. Nesta ocasião ficou estabelecida a paridade entre tratado internacional e lei ordinária).

Já na decisão do RE 466.343, em 03.12.2008, ficou asseverado que os tratados internacionais de direitos humanos que foram regularmente ratificados pelo Brasil, antes da Emenda Constitucional 45/2004, possuem hierarquia supralegal, prevalecendo assim sobre qualquer ato normativo interno, mas encontrando-se abaixo das normas constitucionais. Em síntese: os tratados e convenções internacionais de direitos humanos ratificados antes da EC 45/2004, encontram-se acima das normas infraconstitucionais e aquém das constitucionais, ao passo os instrumentos de direitos humanos ratificados após a EC 45/2004, nos moldes legais adquirem posição de emenda constitucional.

E assim, a partir deste notável julgado, leciona Ingo Wolfgang Sarlet:

É possível afirmar que as relações entre tratados internacionais e a ordem jurídica interna, no que diz respeito à hierarquia dos tratados em relação ao direito interno, uma vez ratificados, obedecem, no Brasil, às seguintes diretrizes:

a) os tratados em geral possuem hierarquia de lei ordinária, prevalecendo a tese da paridade entre tratado e lei;

b) todavia, há hipóteses nas quais não se aplica a regra geral da paridade:

1- os tratados internacionais em matéria tributária prevalecem sobre as leis, a teor do disposto no art. 98 do CTN, que é expresso neste sentido;

2- os tratados em matéria de direitos humanos ratificados antes da EC 45 e/ou não aprovados pelo rito art. $5^{\circ}$, par. $3^{\circ}$, da $\mathrm{CF}$ possuem, de acordo com a atual orientação do STF, hierarquia supralegal;

3- os tratados em matéria de direitos humanos aprovados pelo rito qualificado estabelecido no art. $5^{\circ}$, par. $3^{\circ}$, da $\mathrm{CF}$ serão equivalentes às emendas constitucionais, de tal sorte que terão hierarquia de direito constitucional derivado, cabendo no máximo, sua declaração de inconstitucionalidade por violação dos requisitos formais (procedimento do par. $3^{\circ}$, do art. $5^{\circ}$ ) ou, eventualmente, a prevalecer tal entendimento, por violação das cláusulas pétreas da Constituição Federal. ${ }^{76}$

Tendo em vista que os direitos trabalhistas são considerados como direitos humanos, com previsto no Título II da Constituição (dos direitos e garantias fundamentais), tem-se que os tratados e convenções internacionais de cunho

\footnotetext{
${ }^{76}$ SARLET, Ingo Wolfgang; MARINONI, Luiz Guilherme; MITIDIERO. Curso de direito constitucional. $2^{\mathrm{a}}$ ed. São Paulo: Editora Revista dos Tribunais, 2013, p. 212.
} 
trabalhista que foram objeto de ratificação, antes da Emenda Constitucional 45 ou não aprovados pelo quórum previsto em lei, alcançaram o patamar da supralegalidade, e aqueles que foram ratificados nos moldes legais, após a EC 45/2004, atingem o status de emenda constitucional.

Destaca-se ainda que no âmbito trabalhista a incorporação de tratados e convenções internacionais ganham uma maior facilidade tendo em vista que os direitos previstos no artigo $7^{\circ}$, da Constituição não são taxativos, comportando assim um aumento, elasticidade, afinal estabelece o seu caput a possibilidade da existência de outros direitos, além daqueles já previstos.

Ora, se o próprio Poder Constituinte originário tratou de reconhecer que os direitos trabalhistas previstos no artigo $7^{\circ}$, da $\mathrm{CR} / 88$, são incapazes de proteger e melhorar a condição socioeconômica do trabalhador, e assim permitiu a criação ou soma de outros direitos trabalhistas, o ingresso de tratados e convenções internacionais ao ordenamento jurídico brasileiro dar-se-á até mesmo por questão teleológica constitucional que tem como centro convergente a pessoa humana.

No mesmo sentido defende Ingo Wolfgang Sarlet:

Verifica-se que a regra do art. $7^{\circ}$, cujo incisos especificam os direitos fundamentais do trabalhadores, prevê expressamente, em seu caput ("São direitos dos trabalhadores urbanos e rurais, além de outros que visem à melhoria de sua condição social), a abertura a outros direitos similares. Por derradeiro registre-se que na doutrina brasileira tem prevalecido o entendimento de que tanto o rol de direitos socais dos art. $6^{\circ}$, quanto o elenco dos direitos sociais dos trabalhadores (art. $7^{\circ}$ ) são meramente exemplificativos de tal sorte que ambos os preceitos podem ser perfeitamente qualificados como cláusulas especiais de abertura. ${ }^{77}$

Destaca-se que a incorporação dos tratados e convenções internacionais ao ordenamento jurídico brasileiro decorre de um ato complexo, "que abrange a celebração pelo Poder Executivo, a aprovação pelo Congresso Nacional, mediante decreto legislativo, seguida por decreto do Executivo." 78

De acordo com a Convenção de Viena de 1969 e de 1986, tratado internacional corresponde a um acordo formal, de magnitude internacional, celebrado pelos Estados ou pelas organizações internacionais, regulamentado pelo Direito Internacional, podendo ser realizado mediante um instrumento único ou via dois ou

\footnotetext{
${ }^{77}$ Idem, p. 284.

${ }^{78}$ Idem, p. 285.
} 
mais instrumentos, não sendo obrigatória sua titulação detalhada. O objeto do tratado pode ser de interesse global ou regional.

Convenção é uma espécie de tratado, que participa um número considerável de Estados, menos solene do que o tratado, regulamentando questões especiais de interesse do Direito Internacional.

As condições da validade tanto de um tratado, como de uma convenção internacional são: a) capacidade das partes contratantes; habilitação dos agentes signatários; consentimento mútuo; formalidade e objeto lícito e possível.

Os tratados e convenções vinculam, criam direitos e obrigações tão somente aos Estados que celebraram ou aderiram o respectivo instrumento, não alcançando aqueles Estados que não pactuaram ou não aderiram o documento.

Especificamente na área trabalhista, conforme ensina Maurício Godinho Delgado, havendo conflito entre as normas internas, tratados e convenções internacionais (objeto de ratificação), prevalecerá a norma mais benéfica:

O mesmo se aplica a regras de tratados e convenções internacionais sobre direitos trabalhistas - que têm óbvia natureza de direito humanos em situação de aparente conflito entre regras internacionais ratificadas (Convenções da OIT, por exemplo) e regras internas, prevalecerá o princípio da norma mais favorável ao trabalhador, que no que tange ao critério de solução do conflito normativo, que no que diz respeito ao resultado interpretativo alcançado. ${ }^{79}$

Portanto, os tratados e convenções internacionais podem inclusive prevalecer diante de normas trabalhistas internas, tendo em vista no Direito do Trabalho o conflito das normas é resolvido pela norma mais favorável (horizontal), não sendo aplicável a teoria de Hans Kelsen (vertical).

O núcleo duro do Direito do Trabalho é a proteção e a melhoria de sua condição socioeconômica do trabalhador, observadas em todos os aspectos: de segurança e medicina; patrimonialmente; proteção contra a dispensa; bem estar físico e mental; processualmente e demais aspectos. Daí surge o caráter progressivo deste ramo jurídico especializado.

Os tratados e convenções internacionais que objetivam proteger e melhorar a vida do trabalhador, devem ser objeto de ratificação, afinal ao lado das normas

\footnotetext{
${ }^{79}$ DELGADO, Maurício Godinho. Curso de direito do trabalho. $12^{\mathrm{a}}$ ed. São Paulo: LTr, 2013, p. 150.
} 
constitucionais e infraconstitucionais, foram o arcabouço do Direito do Trabalho, que compõe o patamar mínimo civilizatório, composto por três grandes eixos, conforme leciona Maurício Godinho Delgado:

No caso brasileiro, esse patamar civilizatório mínimo está dado essencialmente, por três grupos de normas trabalhistas heterônomas: as normas constitucionais em geral (respeitadas, é claro, as ressalvas parciais expressamente feitas pela própria Constituição: art. $7^{\circ}$, VI, XIII e XIV, por exemplo); as normas de tratados e convenções internacionais vigorantes no plano interno brasileiro (referidas pelo art. $5^{\circ}, \S 2^{\circ}, \mathrm{CF} / 88$, já expressando uma patamar civilizatório no próprio mundo ocidental em que se integra o Brasil); as normas legais infraconstitucionais que asseguram patamares de cidadania ao indivíduo que labora (preceitos relativos à saúde e segurança no trabalho, normas concernentes à base salarial mínimas, normas de identificação profissional, dispositivos antidiscriminatórios, etc). ${ }^{80}$

Sendo assim, se um dos alicerces dos três grandes eixos do Direito do Trabalho é composto pelos tratados e convenções internacionais, incontroverso que deve manter-se forte e atualizado para garantir a proteção e a melhoria socioeconômica do trabalhador brasileiro.

O transconstitucionalismo através da abertura do catálogo constitucional dos direitos fundamentais, permite a inclusão, recepção na ordem jurídica daqueles direitos considerados como "implicitamente positivados, direitos fundamentais decorrentes do regime e dos princípios constitucionais ou direitos subentendidos nas normas de direitos fundamentais expressamente positivadas". ${ }^{81 . ~ N e s t e ~ s e n t i d o, ~ o s ~}$ tratados e convenções internacionais serviam como um viés de aprimoramento da ordem legal constitucional brasileira, aumentando o espectro dos direitos fundamentais.

Destaca-se ainda que o transconstitucionalismo efetiva até mesmo um dos princípios da República Federativa do Brasil nas suas relações internacionais, previsto no inciso IX, do artigo $4^{\circ}$, da Constituição de 1988, que prevê a cooperação entre os povos para o progresso da humanidade.

\footnotetext{
${ }^{80}$ Idem, 1400.

${ }^{81}$ SARLET, Ingo Wolfgang; MARINONI, Luiz Guilherme; MITIDIERO. Curso de direito constitucional. $2^{\mathrm{a}}$ ed. São Paulo: Editora Revista dos Tribunais, 2013, p. 285.
} 


\section{A IMPORTÂNCIA DAS NORMAS INTERNACIONAIS TRABALHISTA NA PROTEÇÃO DO TRABALHADOR}

A situação do trabalhador que já não era confortável no sistema toyotista de produção, ficou ainda mais delicada após a crise de 2008 que gerou diretos prejuízos à ordem do trabalho.

Destaca-se ainda que a globalização também acabou prejudicando a situação do trabalhador ensejando "a flexibilização das normas que compõem o Direito do Trabalho e, por vezes, a revogação de algumas delas (desregulamentação)." 82

No sistema toyotista de produção o empregado encontra-se cada vez mais vulnerável e desprotegido. Neste modelo de produção, a lógica empresarial é horizontalizada, preocupando-se a empresa tão somente com a atividade principal, descentralizando via terceirização para as atividades periféricas para pequenas e médias empresas ou até mesmo para a contratação informal ou pejotização, ocasião em que o trabalhador torna-se um típico "faz-tudo e mais um pouco".

Conforme ilustra Márcio Túlio Viana:

As empresas atualmente tornaram-se mais horizontais e fisicamente menores, produzindo somente o necessário, enxugando ao máximo seu número de empregados, inovando seus produtos em alta velocidade, fazendo uso cada vez maior da automatização e organização em rede. No entanto, quase sempre, a redução é realmente apenas física, e mesmo assim relativa, pois as pequenas empresas que servem às grandes de certo modo lhes pertencem, já que se submetem-se aos seus desígnios. Palavras que ditam a empresa atual: competitividade, flexibilidade, consumo e conhecimento. $^{83}$

No toyotismo, os produtos devem ser cada vez mais parecidos com os consumidores (que são os trabalhadores). Objetiva-se que o trabalhador identifique-se com o próprio produto que produz. $\mathrm{Na}$ atualidade, não basta que o ser humano seja trabalhador, ele tem que ser ao mesmo tempo trabalhador e consumidor.

A ratificação de direitos internacionais trabalhistas que valorizam e proporcionam melhores condições de trabalho aos empregados, devem ser objeto de ratificação até por questão de efetivação da própria Carta Constitucional que

\footnotetext{
${ }^{82}$ SÜSSEKIND, Arnaldo Lopes. Flexibilização no direito do trabalho. São Paulo: IOB Thomson, 2004 , p. 15.

${ }^{83}$ PUC-MINAS. Ênfase em Direito do Trabalho. Anotações em sala de aula lecionada em 20/10/2012.
} 
reconhece o valor trabalho como fundamento da República Federativa do Brasil, e o considera como base tanto para a ordem econômica, como para a ordem social.

Quanto a constitucionalização do valor do trabalho, ensina Carlos Alberto Reis de Paula:

A Constituição Federal de 1988 positivou e inaugurou - alinhandose ao que há de mais moderno na doutrina e filosofia constitucionalistas - o paradigma jurídico constitucional do Estado Democrático de Direito, a exigir uma nova postura do Poder Judiciário, mais alinhada às ideias concebidas dentro de um contexto jurídico pluralista, democrático, popular e aberto. O trabalho, nessa perspectiva, constitui manifestação de personalidade, e é o instrumento pelo qual alguém passa de indivíduo a pessoa e, decorrentemente disto, a ter respeito no ambiente social em que atua. Pelo trabalho humano se produzem as os bens da vida, enquanto se criam, transformam ou se adaptam os recursos naturais, para a satisfação das necessidades humanas individuais e coletivas. A agregação de valores a esses recursos propicia o surgimento de capital. Sob essa ótica, em um regime capitalista, como o nosso, indiscutivelmente o capital e o lucro têm finalidades sociais. ${ }^{84}$

O trabalho é um valor fonte, uma premissa, pois através dele o cidadão passa a ter acesso a outros direitos, que também não estão devidamente cumpridos pela administração pública (como saúde, educação, moradia, segurança). Assim leciona Ingo Wolfgang Sarlet:

Também no caso do direito ao trabalho é possível identificar a forte conexão com outros direitos fundamentais, reforçando a tese de interdependência e indivisibilidade dos direitos fundamentais. Exemplo digno de nota é o que pode ser vislumbrado no art. $7^{\circ}$, IV, da $\mathrm{CF}$, de acordo com o qual deve ser assegurado ao trabalhador salário "capaz de atender a suas necessidades vitais básicas e às de sua família com moradia, alimentação, educação, saúde, lazer, vestuário, higiene, transporte e previdência social". Isso significa que o salário percebido pelo trabalhador, aqui estabelecido um patamar mínimo, deve ser suficiente para assegurar condições mínimas de bem-estar ao trabalhador e sua família, de modo a garantir o acesso aos bens sociais descritos no dispositivo citado acima. O vínculo direto com o direito-garantia ao mínimo existencial resulta evidente, assim como não se pode desprezar o quanto a garantia da possibilidade de trabalhar, e com isso assegurar seu próprio sustento e dos seus dependentes, constitui dimensão relevante para um direito ao livre desenvolvimento da personalidade

\footnotetext{
${ }^{84}$ PAULA, Carlos Alberto Reis de. A imprescindibilidade da negociação para a realização da dispensa coletiva em face da constituição de 1988 in Temas aplicados de direito do trabalho \& estudos de direito Público. Organização e Coordenação Jerônimo Jesus dos Santos. São Paulo: Ltr, 2012, p. 533.
} 
e da própria noção de autonomia, do ser humano construtor de seu próprio destino. Não é toa que o direito ao trabalho e a proteção do trabalhador estão entre as pautas de reivindicação mais antigas da sociedade e, no campo da definição dos catálogos constitucionais de direitos (e do sistema internacional), já que podem ser encontrados quando da fase inicial de constitucionalismo e ao longo do século XIX, ainda mais a partir da difusão da ideologia socialista, da organização do movimento operário, entre tantos outros fatores, até a sua consagração durante o século XX..$^{85}$

Sendo o trabalho uma ponte para outros direitos fundamentais, os direitos internacionais derivados de tratados e convenções que venha proteger ou melhorar a condição socioeconômica do trabalhador, deve ser objeto de ratificação, incorporação pelo ordenamento jurídico brasileiro, afinal o trabalho é valorizar o ser humano, pois são faces da mesma moeda, pois conforme leciona Friedrich Hegel, "trabalho seria o mediador entre o Homem e o mundo."

Caso a ratificação dos tratados e convenções internacionais trabalhistas seja realizada nos moldes do parágrafo $3^{\circ}$, do artigo $5^{\circ}$, da Constituição, alcançará o status de emenda constitucional, e caso seja ratificado sem o quórum terá força supralegal.

\section{CONCLUSÃO}

O Estado Democrático de Direito é fruto da evolução do constitucionalismo (antigo e moderno), tendo sido construída paralelamente aos direitos fundamentais.

$\mathrm{Na}$ democracia, a figura do Estado existe para o bem estar dos seus cidadãos, e assim os direitos fundamentais formam um complexo, um arcabouço de direitos, considerados como direitos básicos de todo ser humano, e por isso devem ser respeitos e efetivados.

É impossível falar em democracia sem o reconhecimento da dignidade do ser humano, que deve ser analisado também através devida efetivação dos direitos trabalhistas, afinal, o ser humano e o trabalho caminham juntos, um precisando do outro para sua plena realização (conforme visto neste trabalho esta relação iniciou-se na pré-história e perdura até a presente data).

${ }^{85}$ SARLET, Ingo Wolfgang; MARINONI, Luiz Guilherme; MITIDIERO. Curso de direito constitucional. $2^{\mathrm{a}}$ ed. São Paulo: Editora Revista dos Tribunais, 2013, p. 616.

${ }^{86}$ HEGEL, Georg Wilhelm Friedrich. A razão na história. São Paulo: Editora Centauro, 2010, p. 25. 
O trabalho constitui uma forma democrática e progressiva de inclusão social, para a maior parte da população, que é despossuída de capital. A incorporação dos tratados e convenções internacionais de cunho trabalhista ao ordenamento jurídico brasileiro, que aumente, que proteja ou melhore as melhores condições socioeconômicas do trabalhador, representam a efetivação tanto da Constituição, como do Direito do Trabalho, que possuem o ser humano como grundnorm.

O sistema não fecha sem a devida valorização e efetivação ao trabalho e ao emprego, que assim ficam prejudicadas tanto a distribuição de renda, como a inclusão social (de uma parcela significativa da nação), violando até mesmo a efetivação da democracia.

Tendo em vista que o Estado Democrático "é mais do que o governo da maioria, é o governo para todos ${ }^{87}$, deve ser ofertado a classe trabalhadora (que compõe um numero significativo da população de qualquer Estado) meios jurídicos (normas tanto internas como internacionais, via o transconstitucionalismo) que elevem a condição socioeconômica do ser humano através do trabalho.

Por fim, destaca-se assim como o ser humano não vive sozinho, necessitando de relacionar-se com outras pessoas, seja por cunho pessoal e/ou profissional, os Estados também, devem a todo momento estabelecer dialéticas jurídicas com outros países, organizações internacionais, blocos econômicos para manter-se em constante evolução e estabelecer em seu ordenamento jurídico interno (Constituição) uma maior gama possível de direitos humanos (fundamentais) acessíveis aos seus jurisdicionados, proporcionando-lhes a melhor condição de vida possível.

\section{REFERÊNCIAS}

ALEXY, Robert. Teoria dos Direitos Fundamentais. Tradução de Virgílio Afonso da Silva. $2^{\text {a }}$ ed, $2^{\text {a }}$ tiragem alemã. São Paulo: Malheiros Editores, 2011.

ANTUNES, Ricardo. O continente do labor. São Paulo, SP: Boitempo, 2011.

BARROSO. Luís Roberto. Curso de Direito Constitucional Contemporâneo: os conceitos fundamentais e a construção do novo modelo. $4^{\mathrm{a}}$ ed. São Paulo: Saraiva, 2013.

\footnotetext{
${ }^{87}$ BARROSO. Luís Roberto. A dignidade da pessoa humana no direito constitucional comparado: a construção de um conceito jurídico, p. 67.
} 
BARROSO. Luís Roberto. A Dignidade da Pessoa Humana no Direito Constitucional Comparado: a construção de um conceito jurídico à luz da jurisprudência mundial, tradução Humberto Laport de Mello. $2^{a}$ reimpressão. Belo Horizonte: Editora Fórum, 2013.

BLAINEY, Geoffrey. Uma breve história do mundo. São Paulo: Editora Fundamento Educacional, 2010.

CANOTILHO, José Joaquim Gomes. Direito Constitucional e Teoria da Constituição. $7^{\mathrm{a}}$ ed, $13^{\mathrm{a}}$ reimpressão. Coimbra: Edições Almedina, 1941.

CÉSAR, João Batista Martins. A Tutela Coletiva dos Direitos Fundamentais dos Trabalhadores. $1^{\text {a }}$ ed. São Paulo: LTr, 2013.

DELGADO, Gabriela Neves. Direito fundamental ao trabalho digno. São Paulo: LTr, 2006.

DELGADO, Maurício Godinho. Curso de Direito do Trabalho. 12a ed. São Paulo: LTr, 2013.

DELGADO, Maurício Godinho et al (Coords). Constituição da República e Direitos Fundamentais: dignidade da pessoa humana, justiça social e direito do trabalho. São Paulo: LTr, 2012.

FERNANDES, Nadia Soraggi. Ação civil pública trabalhista: forma célere e efetiva de proteção dos direitos fundamentais dos trabalhadores. São Paulo: LTr 2010.

LEITE, Carlos Henrique Bezerra. Curso de Direito Processual do Trabalho. $9^{a}$ ed. São Paulo: LTr, 2011.

NEVES, Marcelo. Transconstitucionalismo. São Paulo: Editora Martins Fontes, 2009.

PANCOTTI, José Antonio. Aspectos Jurídicos das Dispensas Coletivas no Brasil. Revista do Tribunal Regional do Trabalho da $15^{\text {a }}$ Região, ${ }^{\circ}$ 35, 2009.

PAULA. Carlos Alberto Reis de. Palestra proferida em 02 de maio de 2013, na comemoração dos 70 anos da CLT, cerimônia realizada no Tribunal Superior do Trabalho.

PAULA, Carlos Alberto Reis de. A imprescindibilidade da negociação para a realização da dispensa coletiva em face da Constituição de 1988. In: Temas Aplicados de Direito do Trabalho \& Estudos de Direito Público. Organização e Coordenação Jerônimo Jesus dos Santos. São Paulo: Ltr, 2012, p. 533.

PIMENTA, José Roberto Freire. A Tutela Metaindividual Dos Direitos Trabalhistas: uma exigência constitucional. In: PIMENTA, José Roberto Freire et al (Coords). Tutela Metaindividual Trabalhista. São Paulo: LTr, 2009.

PUC-MINAS. Ênfase em Direito do Trabalho. Anotações em sala de aula lecionada em 20/10/2012 
RENAULT, Luiz Otávio Linhares. Que é isto - o direto do trabalho. In: PIMENTA, José Roberto Freire et al. (Coords.). Direito do trabalho: evolução, crise, perspectiva. São Paulo: LTr, 2004.

SARAPU, Thais Macedo Martins. Noções Gerais de Tutela Coletiva. Direito Processual Coletivo. Estado Democrático de Direito. Direito e Devido Processo Legal Coletivo. In: PIMENTA, José Roberto Freire et al (Coords). Tutela Metaindividual Trabalhista. São Paulo: LTr, 2009

SARLET, Ingo Wolfgang; MARINONI, Luiz Guilherme; MITIDIERO. Curso de Direito Constitucional. $2^{\mathrm{a}}$ ed. São Paulo: Editora Revista dos Tribunais, 2013.

SOUTO MAIOR, Jorge Luiz. Curso de Direito do Trabalho: a relação de emprego, volume II. São Paulo: LTr, 2008.

SOUTO MAIOR, Jorge Luiz. Curso de Direito do Trabalho: teoria geral do direito do trabalho, volume I: Parte 1. São Paulo: LTr, 2011.

SOUTO MAIOR. Jorge Luiz. Pai, Afasta de Mim Esse Cálice! Revista LTr Legislação do Trabalho, Volume 12. São Paulo: LTr, 2003.

SOUTO MAIOR, Jorge Luiz; MENDES, Ranúlio; SEVERO, Valdete Souto. Dumping Social nas relações de trabalho. São Paulo: LTr, 2012.

SÜSSEKIND, Arnaldo. Curso de direito do trabalho. $3^{a}$ ed. rev. e atual. Rio de Janeiro: Renovar, 2010.

SÜSSEKIND, Arnaldo Lopes. Flexibilização no direito do trabalho. São Paulo: IOB Thomson, 2004

TEODORO, Maria Cecília Máximo. O Juiz Ativo e os Direitos Trabalhistas. $1^{\mathrm{a}}$ ed. São Paulo: LTr, 2011. 